Review

\title{
Recent Advances in Therapeutic Drug Monitoring of Voriconazole, Mycophenolic Acid, and Vancomycin: A Literature Review of Pediatric Studies
}

\author{
Matylda Resztak*(D), Joanna Sobiak (D) and Andrzej Czyrski (D) \\ Department of Physical Pharmacy and Pharmacokinetics, Poznan University of Medical Sciences, \\ 6 Święcickiego Street, 60-781 Poznań, Poland; jsobiak@ump.edu.pl (J.S.); aczyrski@ump.edu.pl (A.C.) \\ * Correspondence: mresztak@ump.edu.pl; Tel.: +48-(0)6-1854-6433
}

check for

updates

Citation: Resztak, M.; Sobiak, J.; Czyrski, A. Recent Advances in Therapeutic Drug Monitoring of Voriconazole, Mycophenolic Acid, and Vancomycin: A Literature Review of Pediatric Studies. Pharmaceutics 2021, 13, 1991. https://doi.org/10.3390/ pharmaceutics13121991

Academic Editor: Antonello Di Paolo

Received: 24 September 2021 Accepted: 18 November 2021 Published: 23 November 2021

Publisher's Note: MDPI stays neutral with regard to jurisdictional claims in published maps and institutional affiliations.

Copyright: (c) 2021 by the authors. Licensee MDPI, Basel, Switzerland. This article is an open access article distributed under the terms and conditions of the Creative Commons Attribution (CC BY) license (https:// creativecommons.org/licenses/by/ $4.0 /)$.

\begin{abstract}
The review includes studies dated 2011-2021 presenting the newest information on voriconazole (VCZ), mycophenolic acid (MPA), and vancomycin (VAN) therapeutic drug monitoring (TDM) in children. The need of TDM in pediatric patients has been emphasized by providing the information on the differences in the drugs pharmacokinetics. TDM of VCZ should be mandatory for all pediatric patients with invasive fungal infections (IFIs). Wide inter- and intrapatient variability in VCZ pharmacokinetics cause achieving and maintaining therapeutic concentration during therapy challenging in this population. Demonstrated studies showed, in most cases, VCZ plasma concentrations to be subtherapeutic, despite the updated dosages recommendations. Only repeated TDM can predict drug exposure and individualizing dosing in antifungal therapy in children. In children treated with mycophenolate mofetil (MMF), similarly as in adult patients, the role of TDM for MMF active form, MPA, has not been well established and is undergoing continued debate. Studies on the MPA TDM have been carried out in children after renal transplantation, other organ transplantation such as heart, liver, or intestine, in children after hematopoietic stem cell transplantation or cord blood transplantation, and in children with lupus, nephrotic syndrome, Henoch-Schönlein purpura, and other autoimmune diseases. MPA TDM is based on the area under the concentration-time curve; however, the proposed values differ according to the treatment indication, and other approaches such as pharmacodynamic and pharmacogenetic biomarkers have been proposed. VAN is a bactericidal agent that requires TDM to prevent an acute kidney disease. The particular group of patients is the pediatric one. For this group, the general recommendations of the dosing may not be valid due to the change of the elimination rate and volume of distribution between the subjects. The other factor is the variability among patients that concerns the free fraction of the drug. It may be caused by both the patients' population and sample preconditioning. Although VCZ, MMF, and VAN have been applied in pediatric patients for many years, there are still few issues to be solve regarding TDM of these drugs to ensure safe and effective treatment. Except for pharmacokinetic approach, pharmacodynamics and pharmacogenetics have been more often proposed for TDM.
\end{abstract}

Keywords: therapeutic drug monitoring; voriconazole; mycophenolic acid; vancomycin; children

\section{Introduction}

Therapeutic drug monitoring (TDM) is generally defined as a measurement of the drug concentrations in order to optimize dosage and individualize therapy. It should be emphasized that drug concentration's measurement should not be used as the only method of therapy optimization. The priority is to achieve a therapeutic effect without side effects of the drug. However, it is challenging to find the adequate dosages regimens to meet these conditions.

TDM is used mainly for the management of drugs with a narrow therapeutic index, large pharmacokinetics variability, and a reasonable correlation between the drug concen- 
tration and the clinical effects. Both voriconazole (VCZ) and mycophenolic acid (MPA) as well as vancomycin (VAN) meet these criteria.

As there is usually no information on the individual pharmacokinetic parameters of the patient at the start of treatment, reference is made to published recommendations. All subsequent dose adjustments should be made based on the concentration measured and the patient's clinical response.

Application of TDM in routine clinical practice is essential in a specific group of patients such as children. This population demonstrates wide intersubject variability of pharmacokinetic parameters associated with physiological changes during growth and maturation. Additionally, polytherapy, genetic polymorphism, and various serious underlying conditions impact unpredictable dose-exposure relationships to result in treatment failure. For this reason, the number of studies on the pharmacokinetics/pharmacodynamic (PK/PD) of drugs in children has increased significantly in recent years.

In the present review, we focus on TDM of the chosen representatives of antifungal, immunosuppressants, and bactericidal drugs. This article presents recent advances regarding TDM of the abovementioned drugs in pediatric patients. The aim of this review is to more precisely define the impact of pharmacokinetics on TDM and efficacy and toxicity of VCZ, MPA, and VAN treatment.

\section{Voriconazole (VCZ)}

\subsection{Useful PK/PD Parameters}

$\mathrm{VCZ}$ is a second-generation triazole agent with potent spectrum antifungal activity against Aspergillus species, Candida species, and molds that other triazoles are resistant to [1]. In clinical settings, VCZ is the drug of the first choice for the treatment of invasive fungal infections (IFIs) in immunocompromised children with hematologic malignancies and allogeneic hematopoietic stem cell transplantation (allo-HSCT) [2]. However, incomplete response to therapy and toxicity can cause ineffective treatment of IFIs [3]. VCZ is available for clinical use in both adults and children aged 2 years and older as a lyophilized powder for intravenous infusion (IV) and as coated tablets, as well as powder for suspension for oral administration (PO) $[4,5]$. VCZ drug plasma concentrations are unpredictable. Several factors including nonlinear pharmacokinetics, age, body mass index (BMI), cytochrome P450 2C19 polymorphism, drug-drug interaction, and variable oral bioavailability particularly in children are responsible for large inter- and intrapatient variability of VCZ pharmacokinetics (PK) [6].

As a result, it is challenging to optimize daily dosing to achieving therapeutic range in pediatric patients. TDM is recommended throughout treatment to optimize efficacy and minimize adverse reactions $[7,8]$.

The efficacy of VCZ depends on the minimal inhibitory concentration (MIC) of the drug against the pathogen. A preclinical model of disseminated Candida albicans infection has shown that the ratio of the area under the curve (AUC) to MIC (AUC/MIC) is the best predictor of VCZ efficacy [9]. Wang et al. concluded that the free AUC/MIC ratio was higher in 25 predicted clinical responses in IFIs patients [10,11]. Unfortunately, these measurements are difficult to perform in clinical practice, especially in children. Consequently, trough concentrations $\left(C_{\text {trough }}\right)$ are a practical alternative in PK studies of VCZ [11].

\subsection{Timing of Initial TDM and Target Concentration of VCZ}

The initial TDM should be performed as early as possible. The $C_{\text {trough }}$ should be monitored at steady state after 5-7 days of treatment with maintenance dosing. However, when a loading dose is administered, steady state is achieved earlier, and a $\mathrm{C}_{\text {trough }}$ blood sample can be taken from $3-5$ days of therapy $[12,13]$.

A $C_{\text {trough }} / \mathrm{MIC}$ ratio of 2 and 5 or a $C_{\text {trough }}>1 \mathrm{mg} / \mathrm{L}$ was reported as an efficacy target and a $C_{\text {trough }}<4-6 \mathrm{mg} / \mathrm{L}$ as a safety target for VCZ [14-16]. However, the optimal therapeutic VCZ range is still not clearly defined [17]. Numerous observational studies have recommended the therapeutic range of VCZ as $0.5-4.0 \mathrm{mg} / \mathrm{L}$ [18], 1.0-5.0 mg/L [19], 
$1.0-5.5 \mathrm{mg} / \mathrm{L}$ [20,21], $1.0-6 \mathrm{mg} / \mathrm{L}$ [22], and 1.5-4.0 mg/L [23]. However, most studies recommended a $C_{\text {trough }}$ level between 1 and $5.5 \mathrm{mg} / \mathrm{L}$.

Neely et al., who evaluated 46 patients $(0.8-20.5$ years) in a single-center retrospective study, showed that each VCZ serum $C_{\text {trough }}$ of $<1 \mathrm{mg} / \mathrm{L}$ was significantly associated with a 2.6-fold increased risk of death $(p=0.002)$ [24]. Similarly, a relationship between outcome and subtherapeutic $\mathrm{C}_{\text {trough }}$ of VCZ was reported in other TDM studies $[25,26]$. Choi et al. demonstrated that treatment failure was more frequently observed in children with $C_{\text {trough }}<1 \mathrm{mg} / \mathrm{L}$ (success vs. failure, $19.7 \%$ vs. $42.1 \%$ ) [25]. Kang et al. found at 12 weeks of therapy that the poor outcome in the non-TDM group was higher than the TDM group (78.6\% vs. $40.0 \%$ ) [26]. Recently, Hanai et al. designed a systemic review and meta-analysis to determine the optimal trough level of VCZ in the pediatric population. In this study, 211 children with hematologic disorders, solid organ transplantation, and from Asian and non-Asian countries were included. The authors found that the efficacy of IFIs treatment increases significantly with cutoff values of $\geq 1.0 \mathrm{mg} / \mathrm{L}$ [27].

High plasma concentration of VCZ might be associated with an increased risk of toxicity. As VCZ is well tolerated in children with a lower rate of adverse effects (AEs), toxicity targets have not been validated for this population so far [27]. However, several studies have reported the incidence of adverse drug reactions. The most common AEs included hepatotoxicity $[8,20,28-32]$, phototoxicity [28,29], and visual disturbance [30].

A significant relationship between VCZ plasma concentration out of range $>5.5 \mathrm{mg} / \mathrm{L}$ and neurological and skin toxicity $(p=0.0001)$ was established by Soler-Palacín [11]. It is important to note that AEs occur even when VCZ plasma levels are within the therapeutic range as shown by Boast et al. [29]. In their TDM study, performed on 55 children with IFIs, hepatotoxicity occurred in $12.7 \%$ of patients, and none of them had VCZ serum levels $>5 \mathrm{mg} / \mathrm{L}$. Similar observations were presented in the study conducted by Gerin et al. [31]. Hepatotoxicity was reported in 4 children and VCZ was discontinued in 3 of them. All observed VCZ $C_{\text {trough }}$ values were $<5.5 \mathrm{mg} / \mathrm{L}$.

There are major differences between the PK of VCZ in children and adults. The interindividual PK variability appears to be larger in the pediatric population due to faster weight-normalized clearance rate, greater systemic and first-pass metabolism compared with adults [24,25,32]. The oral bioavailability of VCZ in children is equal to $62 \%$ and is lower than in adults $[28,33]$. Additionally, dose-dependent VCZ PK were observed in a pediatric population. Linear PK was reported with VCZ doses between 3 to $4 \mathrm{mg} / \mathrm{kg}$ every $12 \mathrm{~h}$ while nonlinear PK occurred at VCZ doses from 7 to $8 \mathrm{mg} / \mathrm{kg}$ every $12 \mathrm{~h}[6,17]$.

\subsection{The Optimal Dosage Regimen}

Dose recommendation in children changed in 2012, based on PK studies reporting inadequate drug exposure. However, despite dose increasing, many investigators still observe a high proportion of patients with VCZ below the therapeutic range. Barteling et al. evaluated 92 HSTC pediatric patients between 0 and 20 years of age treated with VCZ [3]. It was found that regardless of age and administration route, only $34 \%$ of these patients reached $C_{\text {trough }} \mathrm{VCZ}$ level within the proposed therapeutic range of 1 to $5 \mathrm{mg} / \mathrm{L}$. In addition, $56 \%$ of those patients had $\mathrm{C}_{\text {trough }}$ of $\mathrm{VCZ}<0.5 \mathrm{mg} / \mathrm{L}$. TDM study performed by Tucker et al. in 11 pediatric oncologic/bone marrow transplant patients with a median age of 8 confirmed earlier reports [34]. Authors found that only $50 \%$ of patients achieved $\mathrm{C}_{\text {trough }}$ of VCZ with the recommended dosage median of $6 \mathrm{mg} / \mathrm{kg}$ every $12 \mathrm{~h}$. The rest of the patients required higher doses or more frequent dosage intervals to achieve target $\mathrm{VCZ}$ concentration. Mori et al. provided information on VCZ PK in Japanese children [35]. The number of 24 patients from 0 to 17 years old with a median VCZ doses of $7.6 \mathrm{mg} / \mathrm{kg}$ and $8.1 \mathrm{mg} / \mathrm{kg}$ twice daily for IV and PO administration, respectively, were investigated. In this study, large variability in $\mathrm{C}_{\text {trough }}$ was also observed. The range VCZ $\mathrm{C}_{\text {trough }}$ following PO administration was $0.11-6.19 \mathrm{mg} / \mathrm{L}$ and was comparable with that following IV infusion which was $0.13-5.19 \mathrm{mg} / \mathrm{L}$. Half of the measured $\mathrm{C}_{\text {trough }}$ values did not reach the $1 \mathrm{mg} / \mathrm{L}$ target. Another group of researchers used TDM to guide the VCZ dosing strategy 
in patients $<2$ years [36]. Although the VCZ does not have an official recommendation for children $<2$ years of age, it is used off-label in newborns in special cases [37]. Initial dose of VCZ for 3 patients was $9 \mathrm{mg} / \mathrm{kg}$ intravenously/enterally twice a day. Sets of VCZ $\mathrm{C}_{\text {trough }}$ were obtained and all were subtherapeutic $(0.31-0.89 \mathrm{mg} / \mathrm{L})$. The authors suggested higher initial doses with 3 times/day dosing schedule to achieve VCZ therapeutic level. Doby et al. presented data from 10 pediatric patients aged $<3$ years treated with VCZ of dose $9 \mathrm{mg} / \mathrm{kg} /$ dose every $12 \mathrm{~h}$ who underwent TDM [38]. It was found that $\mathrm{C}_{\text {trough }}$ ranged from $0.1-3.2 \mathrm{mg} / \mathrm{L}$ and only $3(18 \%) \mathrm{C}_{\text {trough }}$ values $>1 \mathrm{mg} / \mathrm{L}$. The authors concluded that higher doses are needed in young children to achieve target concentrations. The study performed by Boast et al. for 55 patients showed that children $<6,6$ to 12 , and $>12$ years of age needed median IV doses of $8.8,7.5$, and $4.0 \mathrm{mg} / \mathrm{kg}$ every $12 \mathrm{~h}$, respectively $(p<0.001)$ [29].

Koto et al. performed a TDM study of VCZ in 20 children aged $<8$ years after stem cell transplantation [8]. The recommended maintenance dose regimen with a median of $10.5 \mathrm{mg} / \mathrm{kg} /$ day was used. It was concluded that more than half of the children did not achieve $\mathrm{C}_{\text {trough }}$ of $1.0 \mathrm{mg} / \mathrm{L}$ at the first and second monitoring of the drug. The authors also showed that children aged $<5$ years had significantly lower $C_{\text {trough }}$ of VCZ in comparison with patients aged 6-12 years. It was reported that higher doses are required in younger patients particularly those receiving PO administration. Another study in the Asian pediatric population was conducted by Kang et al. [26]. The number of 61 children $<19$ years old with hemato-oncological diseases and organ transplantations were divided into TDM $(n=31)$ and non-TDM $(n=30)$ group. The authors found that only $49.4 \%$ of $C_{\text {trough }}$ levels were within the therapeutic range. This study also confirmed that children $<12$ years old require higher doses to achieve VCZ target compared with those $>12$ years of age ( $8.3 \mathrm{mg} / \mathrm{kg}$ and $6.9 \mathrm{mg} / \mathrm{kg}$ every $12 \mathrm{~h}$, respectively).

Most of the TDM VCZ studies were carried out on small groups of children and it was challenging to evaluate statistically significant correlations. Allegra et al. reported a TDM study from 237 children [39]. In all 237 enrolled patients, high interindividual variability of $C_{\text {trough }}$ was proved (range $0.69-3.18 \mathrm{mg} / \mathrm{L}$ ). For children who received IV administration, and with higher serum creatinine levels, higher $C_{\text {trough }}$ were found $(p<0.001)$. A positive and significant correlation between $C_{\text {trough }}$ and age was observed $(p=0.036)$. In patients receiving PO administration, the authors observed a positive correlation between VCZ dose and drug plasma exposure $(p<0.001)$. Moreover, they concluded that sex significantly influenced VCZ levels, with a higher median drug concentration for the male group $(p<0.001)$. A statistically significant group of children competed in a study by Liu et al. [2]. The authors evaluated 107 pediatric patients aged 0.1-11.1 years. In this study, the dose-exposure correlation was investigated and appropriate initial dosing regimens were evaluated. Similar to published results, high VCZ $\mathrm{C}_{\text {trough }}$ variability especially in patients aged $<2$ years and those aged 2-12 years was observed. They found that only $47.7 \%$ of patients reached the VCZ therapeutic level of $1.0-5.5 \mathrm{mg} / \mathrm{L}$. In their opinion, in a group aged $<2$ years dose of 5 to $<7 \mathrm{mg} / \mathrm{kg}$ significantly increased the chance to reach the target of VCZ concentration compared with the 3 to $<5 \mathrm{mg} / \mathrm{L}$ dose recommended.

Recent studies also showed that the recommended dosages did not lead to adequate therapeutic drug levels in the majority of children. Lampers et al., in a study with a cohort of 21 pediatric patients, reported a high percentage of $\mathrm{VCZ}_{\text {trough }}<1 \mathrm{mg} / \mathrm{L}$ [5]. Upon first measurement, only $52.4 \%$ of children reached $C_{\text {trough }}$ between $1-6 \mathrm{mg} / \mathrm{L}$. The dose adaptations were needed to achieve VCZ therapeutic levels. $\mathrm{Hu}$ et al. reported that Asian children required lower doses of $\mathrm{VCZ}$ than the recommended to achieve the target range of $1.0-5.5 \mathrm{mg} / \mathrm{L}$ [20]. Authors observed that only 50\% of children (21/42) aged 2-14 years old had initial $C_{\text {trough }} \geq 1 \mathrm{mg} / \mathrm{L}$ with a range from $0.02-9.35 \mathrm{mg} / \mathrm{L}$. However, only $28 \%$ of those patients had the dose adjustment. The average oral and IV adjusted doses were $7.7 \mathrm{mg} / \mathrm{kg}$ and $5.6 \mathrm{mg} / \mathrm{kg}$ twice a day to achieved VCZ therapeutic levels. Zhao et al., in a TDM study of children aged 1 to $<18$, concluded that patients $<12$ years tended to have a higher intraindividual PK variability [40]. More than $50 \%$ of 94 pediatric patients did not reach the VCZ therapeutic range at the initial $C_{\text {trough }}$ (ranged from 0.04 to $16.11 \mathrm{mg} / \mathrm{L}$ ). 
The younger children, $\leq 12$ years, obtained significantly lower $C_{\text {trough }}(p=0.0096)$. The median dosage needed to achieve adequate prophylaxis and treatment of VCZ by age group was additionally investigated by Duehlmeyer et al. [41]. It was found that only $50 \%$ of VCZ $\mathrm{C}_{\text {trough }}$ levels for 107 children were considered within the therapeutic range. The authors established the median dose by age $\leq 6,7-12.9, \geq 13$ as follows: $8.1,6.7$, and $3.3 \mathrm{mg} / \mathrm{kg}$. Recently, another TDM study including 27 children aged 2-12 years, was performed [42]. The authors aimed to evaluate VCZ monitoring in children with IFIs after the administration of new dosages. It was found that new dosing led to a higher rate of adequate levels of VCZ, compared to previous studies. However, still, $35.8 \%$ of VCZ $\mathrm{C}_{\text {trough }}$ were outside the therapeutic range; $27.5 \%$ were subtherapeutic and $8.3 \%$ were supratherapeutic. The authors concluded that the estimated dose was significantly higher in children $<8$ years than in those $\geq 8$ years $(21$ vs. $16.5 \mathrm{mg} / \mathrm{kg} /$ day; $p=0.02$ ).

\subsection{Factors Affecting Serum Concentration in TDM}

A growing number of studies have documented that CYP2C19 polymorphism makes a crucial contribution to the extensive pharmacokinetic variability of VCZ [4]. VCZ is metabolized by primary by liver through CYP2C19 and to a lesser extent CYP2C9 to its main circulating N-oxide metabolite. CYP2C19 phenotype variants are known to be strongly correlated with differences in the therapeutic plasma concentration of VCZ [43]. Genetic polymorphism of CYP2C19 is associated with 30\% to 50\% variation in VCZ metabolism between individuals [44]. The wild-type allele CYP2C19*1 encodes normal function and homozygous $\left(C Y P 2 C 19^{*} 1^{*} 1\right)$ considered as the normal metabolizers (NMs). The notable functional allelic variants known to impact VCZ pharmacokinetics are CYP2C19*2,*3, and *17. CYP2C19*2, and CYP2C19*3 homozygous alleles are classified as poor metabolizers (PMs) phenotype while heterozygous alleles are classified as intermediate metabolizers (IMs) phenotype. Patients with CYP2C19*17 allele are classified as ultrarapid metabolizers (URMs) phenotype $[4,45,46]$. The proportions of CYP2C19 PMs vary with race ethnicity. It has been shown that PMs phenotype is present in only about $3-7 \%$ of Caucasians and African Americans and 12-23\% of Asians population, with a higher frequency in Japanese than in Chinese patients $(21.3 \%$ vs. $13.7 \%$, respectively) $[35,45,47]$.

Limited data on the impact of CYP2C19 genetic variants on the VCZ pharmacokinetics in pediatric patients are available. Hick et al. elaborated the impact of CYP2C19 genotypes on VCZ plasma concentrations in 33 immunocompromised children (aged 1-19 years) [48] VCZ $C_{\text {trough }}$ between 1 and $6 \mathrm{mg} / \mathrm{L}$ were considered to be therapeutic. The authors found that CYP2C19 genotypes were associated with $\mathrm{VCZ} \mathrm{C}_{\text {trough }}(p=0.002)$. VCZ dose normalized plasma $C_{\text {trough }}$ were significantly lower in URMs phenotype patients (median $0.01 \mathrm{mg} / \mathrm{L} / \mathrm{mg} / \mathrm{kg} ; p=0.04$ ) and significantly higher in PMs phenotype patients (median $0.62 \mathrm{mg} / \mathrm{L} / \mathrm{mg} / \mathrm{kg} ; p=0.04$ ); than in EMs phenotype patients (median $0.07 \mathrm{mg} / \mathrm{L} / \mathrm{mg} / \mathrm{kg}$ ). It was shown that children who had URMs phenotype never achieved VCZ target range at any dose. The authors concluded that CYP2C19*17 homozygous pediatric patients would require higher doses to reach the VCZ target concentrations. Another analysis, performed by Narita et al., in 37 Japanese patients in the pediatric group (aged 1-15 years) showed that $C_{\text {trough }}$ of VCZ were significantly higher $(p=0.004)$ in the PMs and IMs metabolizer groups compared with the EMs metabolizers and URMs groups; medians were 0.54 and $0.09 \mathrm{mg} / \mathrm{L}$, respectively [43]. The authors concluded that in patients with $\mathrm{VCZ} \mathrm{C}_{\text {trough }}$ lower than the target range, daily doses had to be increased according to reports from western countries. Teusing et al. analyzed 20 children with a median age of 10.9 years undergoing HSCT who received CYP2C19 genotype-directed dosing [49]. Results showed a significant difference in doses and time required to achieve $C_{\text {trough }}$ of VCZ for different CYP2C19 genotypes. The algorithm according to the individual CYP2C19 genotype was performed. The authors found that in the follow-up study, no patients who had $\mathrm{C}_{\text {trough }}$ lower than $<1 \mathrm{mg} / \mathrm{L}$ and higher than $>5.5 \mathrm{mg} / \mathrm{L}$ and showed a statistically significant $(p<0.001)$ decrease in time to reach the VCZ target range of 1-5.5 mg/L from 29 to 6.5 days when genotype-guided dosing was used. 
Due to the fact that VCZ is an inhibitor and a substrate for CYP2C19, 2C9, and 3A4, drug-drug interactions with agents metabolized by these pathways are common. Coadministration of these drugs could be a rationale for VCZ TDM. Liu et al. reported that omeprazole significantly increased the $C_{\text {trough }}$ of VCZ in pediatric patients $(p=0.032)$ [2] Similar findings were also observed in a study by $\mathrm{Hu}$ et al. [20]. Proton pump inhibitors (PPIs) significantly increased $\mathrm{C}_{\text {trough }} \mathrm{VCZ}$ compared to those with VCZ administration only $(p=0.028)$. On the other hand, Spriet et al. did not find a significant impact of omeprazole on VCZ PK $(p=0.78)$ [28]. The following drug-drug interaction was reported by Soler-Palacín [11]. Low plasma VCZ levels were observed until carbamazepine was discontinued from treatment. In recent studies on the pediatric population, the association between C-reactive protein levels (CRP) and $C_{\text {trough }}$ was observed $[42,50,51]$. Luo et al. reported a significant correlation of $C R P$ and $C_{\text {trough }}$ VCZ for children in age 11-18 years but not in the age of $2-10$ years.

Serum albumin levels decrease in critically ill patients with chronic infection. Hypoalbuminemia is known, usually resulting in higher free drug concentration in plasma, and in that case, the effect of the drug may be increased. The impact of hypoalbuminemia on $\mathrm{C}_{\text {trough }} \mathrm{VCZ}$ in pediatric patients was found [2,42]. The authors suggested that optimizing albumin levels could maximize the treatment effect. In another study, Vanstraelen et al. concluded that the measured VCZ total concentration should be interpreted with caution, especially in patients with hypoalbuminemia and VCZ $\mathrm{C}_{\text {trough }}$ close to the upper limit of the therapeutic range [52]. The authors postulated to consider dose adjustments for patients with adverse events potentially related to an increased unbound plasma concentration. Additionally, the simultaneous measurement of both the total and unbound VCZ concentration might provide a more complete understanding of VCZ PK variability observed in patients $[52,53]$.

\subsection{The Dosing in Different Groups of Patients}

Age is one of the most important factors influencing VCZ plasma exposure, as VCZ clearance was shown to be much higher in children under the age of 12 , and oral bioavailability of VCZ is lower in children compared to that in adults [5]. Early published data suggest that the recommended dosages for pediatric patients were inadequate to achieve $\mathrm{C}_{\text {trough }}$ greater than $1 \mathrm{mg} / \mathrm{L}$, especially for younger children $(<12$ years) $[28,32,34,54]$. In the study performed by Spriet et al., 10 children (0.9-18 years of age) with IV and PO median dose of $6.95 \mathrm{mg} / \mathrm{kg}$ every $12 \mathrm{~h}$, were examined. The authors confirmed that VCZ levels varied widely in children; they ranged from 0.09 to $4.90 \mathrm{mg} / \mathrm{L}<12$ years of age and from 0.11 to $1.71 \mathrm{mg} / \mathrm{L}$ in patients $>12$ years old. They found that levels of VCZ $\mathrm{C}_{\text {trough }}$ were within the therapeutic range in only one-third of cases. No correlation between $\mathrm{C}_{\text {trough }}$ and administered dosage was observed. They concluded that starting with IV dose of VCZ at least $7 \mathrm{mg} / \mathrm{kg}$ every $12 \mathrm{~h}$ and performing TDM regularly may guarantee the effectiveness of therapy. Higher daily dosages were suggested by Gerin et al. [31]. The authors evaluated $C_{\text {trough }}$ of VCZ obtained from 6 infants and 10 children after IV administration. In these groups, $C_{\text {trough }}<1 \mathrm{mg} / \mathrm{L}$ was observed in $77 \%$ and $47 \%$ cases, respectively. The authors found that increased daily dosages in the range of $20-32 \mathrm{mg} / \mathrm{kg}$ in some pediatric patients were necessary to achieve $C_{\text {trough }}>1 \mathrm{mg} / \mathrm{L}$. This was consistent with the findings of Brüggemann et al., who performed TDM practice in 18 children aged from 0 to 18 years [55]. In $44 \%$ of patients, the first $C_{\text {trough }}$ of $\mathrm{VCZ}$ was lower than the therapeutic target. Choi et al., in TDM studies of 27 patients $<19$ years, demonstrated a significant correlation between $\mathrm{PO}$ doses and $\mathrm{C}_{\text {trough }}$ of VCZ in patients $\leq 6$ years old $(p=0.027)$ [25]. It was found that younger children needed higher PO doses compared to older pediatric groups (median dose of 8.9 vs. $4.2 \mathrm{mg} / \mathrm{kg}$ every $12 \mathrm{~h}, p<0.001$ ). In another study, Soler-Palacín et al., evaluated 30 immunocompromised children aged 0-17, who were treated with VCZ at a median dose of $20 \mathrm{mg} / \mathrm{kg} /$ day [11]. As much as $50 \%$ of the $\mathrm{C}_{\text {trough }} \mathrm{VCZ}$ plasma samples were reported as $<1 \mathrm{mg} / \mathrm{L}$. Finally, a total of $73 \%$ of patients required a dose adjustment. The authors concluded that patients $<5$ years of 
age needed a median dose of $38 \mathrm{mg} / \mathrm{kg} /$ day while patients $>5$ years of age median dose of $15 \mathrm{mg} / \mathrm{kg} /$ day to achieve VCZ therapeutic levels. Similarly, the study conducted by Pieper et al. showed that the recommended doses were too low to achieve adequate VCZ levels in younger children [56]. In a group of 72 children (0.2-18 years of age) with a median maintenance dosage of $4.8 \mathrm{mg} / \mathrm{kg}$ twice daily, $\mathrm{C}_{\text {trough }}$ of $\mathrm{VCZ}$ were within a range of $<0.2$ to $14.9 \mathrm{mg} / \mathrm{L}$, and no correlation to dose was observed ( $p=0.07$ ). Of the samples, in $22 \%, 42 \%$, and $58 \%, \mathrm{VCZ}$ concentrations were $<0.2, \leq 0.5$, and $\leq 1.0 \mathrm{mg} / \mathrm{L}$, respectively. Dosage modification was needed in 31 cases.

High variability of the VCZ PK is also observed in patients with chronic liver dysfunction [57]. A study performed by Wang et al. in adult populations demonstrated that clearance (CL) of VCZ decreased with increasing severity of hepatic failure according to the Child-Pugh classification [58]. Patients with mild to moderate (Child-Pugh Class A and B) liver cirrhosis demonstrated higher plasma exposure of VCZ compared with those with normal hepatic function. Thus, the maintenance dose should be halved in those patients. Additionally, Lin et al. noted an increase of VCZ terminal half-life of about five times in Child-Pugh Class $C$ adult patients [59]. Due to no dosage recommendation of Class C patients, the authors suggested closely monitoring VCZ to adjust appropriate dosage based on the obtained results to avoid serious adverse events. To the best of our knowledge, such studies have not been conducted in the pediatric population.

\subsection{Additional Information Useful for VCZ TDM}

The success of VCZ TDM depends on the quality of analytical methods used for the determination of VCZ concentrations in biological fluids. Numerous HPLC methods with UV, FLD, and MS detection have been presented as common in VCZ TDM [7,53,60,61]. The extremely important aspect of the TDM practice, especially in pediatric patients, is the amount of sample that is required for analysis. HPLC-MS methods are attractive because they accept a small sample size, even $50 \mu \mathrm{L}$ [62]. Another point to consider is the sample pretreatment procedure. It is important to simplify the analytical procedure so that it can be successfully used in TDM. Some published HPLC methods still apply liquid-liquid extraction [57]. However, those methods are time-consuming and may cause errors resulting from changes in extraction efficiency. Some authors suggested an alternative technique of VCZ extraction based on one-step plasma protein precipitation, which are faster and easier to perform $[53,63]$.

\section{Mycophenolic Acid (MPA)}

\subsection{MPA Characteristics}

In children treated with MPA, similarly as in adult patients, the role of TDM for MPA has not been well established and is still undergoing continued debate, whereas TDM for other immunosuppressants such as cyclosporine (CsA), tacrolimus (Tac), or sirolimus has already been implemented [64,65]. MPA was firstly registered in prevention of acute rejection after renal transplantation; however, its activity is used not only after solid organ, intestinal, and HSCT but in other diseases, mainly of autoimmune background (lupus nephritis, nephrotic syndrome) as well. MPA TDM is recommended in pediatric patients, but it is still not a routine practice although numerous studies proved the advantage of dose adjustment based on TDM [66-73]. Our review includes studies on the MPA TDM in children after renal transplantation [67,74-81], other organ transplantation such as heart [82,83], liver [72], or intestine [65], children after hematopoietic stem cell transplantation [84-89] or cord blood transplantation [90], and children with lupus [71,73,91-96], nephrotic syndrome [69,70,97-107], Henoch-Schönlein purpura [108], and other autoimmune diseases [109].

MPA is an active form of mycophenolate mofetil (MMF). It is also administered as enteric-coated mycophenolate sodium (EC-MPS); however, the usage of this formulation is limited in pediatric patients [66]. MPA is a selective, noncompetitive, and reversible inosine monophosphate dehydrogenase (IMPDH) inhibitor [65]. IMPDH is the rate-limiting 
enzyme in de novo synthesis of guanosine nucleotides. In this manner, MPA suppresses cell-mediated immune responses and antibody formation by inhibiting the proliferation of T and B-lymphocytes, which are more dependent on the novo pathway than other cell types [110,111]. MPA is characterized by considerably mild adverse effects if compared with other immunosuppressants (e.g., CsA, Tac). The main obstacle during MMF treatment is the variability of its pharmacokinetics [67], which precludes obtaining the efficient MPA concentrations in plasma.

\subsection{Useful PK/PD Parameters}

MPA $C_{\text {trough }}$ is not a good surrogate for its overall exposure $[87,98]$ and does not correlate with clinical outcomes in pediatric renal transplant recipients [75]. One of the factors that enables using $\mathrm{C}_{\text {trough }}$ in MPA TDM is probably concomitant CsA administration as CsA inhibits MPA enterohepatic recirculation $[65,110]$. In children treated with MMF and Tac, the contradictory observation was made by Todorova et al. [112], who found a statistically significant correlation between MPA exposure and MPA trough levels supporting the use of trough levels to monitor exposure. Generally, MPA TDM should be based on MPA exposure, which is expressed by the area under the concentration-time from 0 to $12 \mathrm{~h}$ curve $\left(\mathrm{AUC}_{0-12}\right)$. In children treated with $\mathrm{MMF}$ due to different than renal transplantation indication, MPA $C_{\text {trough }}$ is frequently also analyzed in relation to TDM.

Whereas TDM based on $C_{\text {trough }}$ would be easier and more convenient, MPA AUC ${ }_{0-12}$ estimation is difficult to perform in clinical practice, as it requires multiple blood sampling within $12 \mathrm{~h} \mathrm{[71].} \mathrm{The} \mathrm{approach} \mathrm{that} \mathrm{facilitates} \mathrm{the} \mathrm{MPA} \mathrm{exposure} \mathrm{estimation} \mathrm{by} \mathrm{requiring}$ only a few blood samples collection is the limited sampling strategy (LSS). LSS might be developed based on multiple linear regression [98,105,113] or Bayesian estimation [71,103]. Those LSSs that include MPA concentrations within 2-3 h after drug administration might facilitate TDM. Some LSSs have been applied in clinical practice to adjust MMF dose, e.g., Berger et al. [75] conducted TDM-adjusted MMF dosing in children after renal transplantation based on LSS-calculated AUC and Carlone et al. [88] applied LSS for MPA $\mathrm{AUC}_{0-12}$ estimation and adjusted MMF oral dose to achieve target MPA AUC $0-12$ in children treated with MMF and Tac after HSCT.

\subsection{Timing of Initial TDM and Target Parameters of MPA \\ 3.3.1. TDM Based on Pharmacokinetics}

Based on the recommendations given for adult patients, the recommended target range of MPA AUC $\mathrm{AL}_{0-12}$ in pediatrics is $30-60 \mathrm{mg} \cdot \mathrm{h} / \mathrm{L}[65,110]$; however, these values differ among MMF indications.

Filler at el. [114] suggested that MPA minimum exposure of $1.3 \mathrm{mg} / \mathrm{L}$, which is equivalent to an $\mathrm{AUC}_{0-12}$ of $30 \mathrm{mg} \cdot \mathrm{h} / \mathrm{L}$, may prevent the formation of donor-specific antibodies. The authors observed that those pediatric renal transplant recipients who formed donorspecific antibodies had significantly lower minimum MPA levels $(0.27 \pm 0.23 \mathrm{mg} / \mathrm{L})$ than those who did not $(0.47 \pm 0.18 \mathrm{mg} / \mathrm{L})$.

In children after intestinal transplantation, $\mathrm{MPA} \mathrm{AUC}_{0-12}$ monitoring using a target of $30 \mathrm{mg} \cdot \mathrm{h} / \mathrm{L}$ contributed to the improvement of graft function and the limitation of adverse events such as renal failure [66]. In children after heart transplantation, treated with MMF and Tac, adjusted MMF dose to achieve MPA $C_{\text {trough within } 0.8-2.0 \mu \mathrm{g} / \mathrm{mL}}$ resulted in an acceptable profile of MPA-related adverse effects without significant impact on graft outcome [82].

In children after HSCT, treated with MMF and Tac, it was proved that adjusting MMF dose to achieve MPA $\mathrm{AUC}_{0-12}$ within $30-60 \mu \mathrm{g} \cdot \mathrm{h} / \mathrm{mL}$ allowed a reduction in the incidence of acute and chronic GvHD [88]. Windreich et al. [87] proved that individualized MMF dosing by targeting MPA AUC was feasible, safe, and effective in the early phase after allo-HCT in children treated with MMF and CsA. In their study, optimal MPA exposure of $\mathrm{AUC}_{0-24}$ within 40 to $80 \mu \mathrm{g} \cdot \mathrm{h} / \mathrm{mL}$ and desired steady-state levels were achieved after switching from short infusion regimen to a continuous infusion (over $24 \mathrm{~h}$ ). During 
continuous infusion, MMF dose was adjusted to achieve MPA steady-state concentration $\left(\mathrm{C}_{\mathrm{sS}}\right)$ within 1.7 to $3.3 \mu \mathrm{g} / \mathrm{mL}$. Moreover, none of the patients showed secondary peaks what suggested the lack of enterohepatic recirculation of MPA. In children who underwent cord transplantation, Harnicar et al. [90] intensified MMF dosing from $12 \mathrm{~h}$ intervals to $8 \mathrm{~h}$ intervals to augment GVHD prophylaxis and found that patients with a mean week 1 and 2 MPA $C_{\text {trough }}<0.5 \mu \mathrm{g} / \mathrm{mL}$ had an increased day 100 grade III and IV acute GVHD (26\% vs. $9 \%$ ), and those who received a low total daily MMF dose and had a low mean week 1 and 2 MPA trough had a $40 \%$ incidence of acute GVHD. The upper threshold for MPA $\mathrm{C}_{\text {trough }}$ was established as $2 \mu \mathrm{g} / \mathrm{mL}$ based on solid organ transplantation literature. The study [90] supported intensified MMF dosing and MPA trough level monitoring early after transplantation in double-unit cord blood transplantation recipients. It must be emphasized that this study included both adult and pediatric patients. In children after allo-HSCT, who received MMF concomitantly with CsA, Kim et al. [89] observed the concentrations of dose-normalized fMPA within 1 to $773 \mathrm{ng} / \mathrm{mL}$ and found that some patient-specific covariates affected unbound MPA pharmacokinetics (body weight, creatinine clearance, and total bilirubin). The desired therapeutic range of $\mathrm{AUC}_{0-8}$ for $\mathrm{fMPA}$ was assumed as 200-250 ng.h/mL.

In Sagcal-Gironella et al. study [93], MPA $\mathrm{AUC}_{0-12} \geq 30 \mathrm{mg} \cdot \mathrm{h} / \mathrm{L}$ was associated with improved disease control; therefore, they concluded that disease activity change over time might be related to MPA exposure in childhood-onset systemic lupus erythematosus. Woillard et al. [71] suggested that a target value of $45 \mathrm{mg} \cdot \mathrm{h} / \mathrm{L}$ could be proposed in the context of MPA TDM in studied children. The authors observed that the risk of active disease was 21 times greater in patients with an AUC $<44 \mathrm{mg} \cdot \mathrm{h} / \mathrm{L}$ and 59 times greater for patients with a value of AUC/dose $<0.06$. Similar observation was found by GodronDubrasquet et al. [73], who found the highest response rates of $89 \%$ in patients with MPA AUC $>45 \mathrm{mg} \cdot \mathrm{h} / \mathrm{L}$ and concluded that this value may be considered as a target value in pediatric lupus nephritits. In their opinion, MPA TDM leading to individualized dosing may improve efficacy of MMF. Ye et al. [96] observed increased levels of MPA exposure with decreased incidence odds of diabetes, acute kidney injury, or pneumonia and proposed even higher target exposure levels of MPA AUC for clinical practice (100.39 and $50.20 \mathrm{mg} \cdot \mathrm{h} / \mathrm{L}$ for $\mathrm{AUC}_{0-24}$ and $\mathrm{AUC}_{0-12}$, respectively) in systemic lupus erythematosus children. In other study, Ye et al. [94] suggested that target exposure levels might amount to 98.71 and $49.36 \mathrm{mg} \cdot \mathrm{h} / \mathrm{L}$ for $\mathrm{AUC}_{0-24}$ and $\mathrm{AUC}_{0-12}$, respectively. Chen et al. [92] evaluated target MPA pharmacokinetic parameters using different analysis and criteria and found that in studied children, an $\mathrm{AUC}_{0-12}$ threshold of $39 \mu \mathrm{g} \cdot \mathrm{h} / \mathrm{mL}$ or a $\mathrm{C}_{\text {trough }}$ of $1.01 \mu \mathrm{g} / \mathrm{mL}$ was associated with the lowest risk of active disease (ROC analysis), whereas an $\mathrm{AUC}_{0-12}$ of $<34 \mu \mathrm{g} \cdot \mathrm{h} / \mathrm{mL}$ or a $\mathrm{C}_{\text {trough }}<1.2 \mu \mathrm{g} / \mathrm{mL}$ (logistic regression analysis) might be associated with active disease. An $\mathrm{AUC}_{0-12}<32 \mu \mathrm{g} \cdot \mathrm{h} / \mathrm{mL}$ or a $\mathrm{C}_{\text {trough }}<1.1 \mu \mathrm{g} / \mathrm{mL}$ was associated with suboptimal clinical outcome, whereas an $\mathrm{AUC}_{0-12}>50 \mu \mathrm{g} \cdot \mathrm{h} / \mathrm{mL}$ or a $\mathrm{C}_{\text {trough }}>1.7 \mu \mathrm{g} / \mathrm{mL}$ was associated with disease control (exposure-response modeling) [92]. There has not been much information regarding the upper limit of MPA AUC, and further studies are still required in this field; however, according to Woillard et al. [71], AUC values $>60 \mathrm{mg} \cdot \mathrm{h} / \mathrm{L}$ in children with systemic lupus erythematosus provided no additional benefit and increased the incidence of adverse drug effects.

In children with nephrotic syndrome, MPA AUC ${ }_{0-12}$ should exceed $45 \mathrm{mg} \cdot \mathrm{h} / \mathrm{L}[69,102]$ or even $60 \mu \mathrm{g} \cdot \mathrm{h} / \mathrm{mL}$ [97] to prevent from the relapse. Hibino et al. [100] postulated MPA $\mathrm{AUC}_{0-24}$ of $98.71 \mathrm{mg} \cdot \mathrm{h} / \mathrm{L}$ or $\mathrm{AUC}_{0-12}$ of $49.36 \mathrm{mg} \cdot \mathrm{h} / \mathrm{L}$ as the targeted exposure. In children with idiopathic nephrotic syndrome, Saint-Marcoux et al. [103] observed higher AUC in patients in remission $(63.2 \pm 27.2 \mathrm{mg} \cdot \mathrm{h} / \mathrm{L})$ than in the other groups $(21.3 \pm 9.7 \mathrm{mg} \cdot \mathrm{h} / \mathrm{L}$, $34.3 \pm 18.8 \mathrm{mg} \cdot \mathrm{h} / \mathrm{L}, 30.5 \pm 6.0 \mathrm{mg} \cdot \mathrm{h} / \mathrm{L}$ in the relapse, partial relapse, and partial remission groups, respectively) as well as higher dose-corrected AUC in the remission than in the relapse group $(1.50 \pm 0.61$ vs. $1.1 \pm 0.41)$. Gellerman et al. [104] found that MPA AUC ${ }_{0-12}$ of $60-80 \mu \mathrm{g} \cdot \mathrm{h} / \mathrm{mL}$ range seemed suitable for maintaining remission on MMF monotherapy as they did not observe a single relapse. The authors aimed at MPA $C_{\text {trough }}$ of $>2 \mu \mathrm{g} / \mathrm{mL}$, 
which could be achieved with a dose of $1000-1200 \mathrm{mg} / \mathrm{m}^{2}$ BSA. After administrating highly variable MMF mean doses ranging from 510 to $1435 \mathrm{mg} / \mathrm{m}^{2} /$ day, the mean MPA AUC amounted to 70 (range 39-113) $\mu \mathrm{g} \cdot \mathrm{h} / \mathrm{mL}$. Baudouin et al. [101] compared MPA pharmacokinetics one and six months after initiation of treatment and found its high variability and no differences between MPA $C_{\text {trough }}(2.74 \pm 1.16 \mu \mathrm{g} / \mathrm{mL}$ and $3.09 \pm 1.50 \mu \mathrm{g} / \mathrm{mL})$ and $\mathrm{AUC}_{0-12}$ $(53.01 \pm 21.80 \mu \mathrm{g} \cdot \mathrm{h} / \mathrm{mL}$ and $54.47 \pm 16.92 \mu \mathrm{g} \cdot \mathrm{h} / \mathrm{mL})$ in children with steroid-dependent nephrotic syndrome. MPA $\mathrm{AUC}_{0-12}$ values were, however, close to the upper limit of the target value for renal transplant recipients. Gellerman et al. [70] aimed at target plasma MPA $C_{\text {trough }}$ of $1.5-2.5 \mu \mathrm{g} / \mathrm{mL}$ in one group and CsA target $C_{\text {trough }}$ of $80-100 \mathrm{ng} / \mathrm{mL}$ in the second group and found that MMF might be a less nephrotoxic treatment option in children with frequently relapsing steroid-sensitive nephrotic syndrome, although MMF was inferior to CsA in preventing relapses (patients without relapse: $64 \%$ vs. $85 \%$ for MMF and CsA, respectively). In their opinion, high MPA AUC (>50 $\mu \mathrm{g} \cdot \mathrm{h} / \mathrm{mL})$ might have similar therapeutic efficacy as treatment with CsA [70]. Fujinaga et al. [115], after adjusting MMF based on MPA $C_{\text {trough, }}$, concluded that CsA appears to be more effective than MMF for maintaining remission in children with severe steroid-dependent nephrotic syndrome after a single infusion of RTX. In this study, MMF dose was adjusted to maintain MPA $\mathrm{C}_{\text {trough }}$ of $2-5 \mu \mathrm{g} / \mathrm{mL}$, and no AUC adjustment was made, whereas CsA was adjusted to maintain $C_{2}$ level of 400-500 ng/mL. Tong et al. [106] observed that children with MPA AUC value of only $\geq 30 \mu \mathrm{g} \cdot \mathrm{h} / \mathrm{mL}$ tended to require smaller steroid dosages and experience greater remission rates than patients with MPA AUC $<30 \mu \mathrm{g} \cdot \mathrm{h} / \mathrm{mL}$.

MMF was recently administered in children with Henoch-Schönlein purpura by Hackl et al. [108], who found that estimated MPA $\mathrm{AUC}_{0-12}>56.4 \mathrm{mg} \cdot \mathrm{h} / \mathrm{L}$ was a predictor for complete remission within 3 months. The initial dose was later adjusted according to the result of repeated TDM (performed within 3 months of therapy onset and yearly thereafter) to target MPA $\mathrm{AUC}_{0-12}$ values $>30 \mathrm{mg} \cdot \mathrm{h} / \mathrm{L}$. The authors did not encounter any adverse event requiring discontinuation of treatment during MMF treatment and concluded that MMF was a safe and potentially effective secondary treatment option for children with Henoch-Schönlein purpura to achieve and maintain long-term remission without serious side effects.

Although MPA $C_{\text {trough }}$ generally seems not useful for TDM [71,102], some studies proved its utility in children with nephrotic syndrome. Gellerman et al. [70] found that $C_{\text {trough }}$ levels of $3.5 \mu \mathrm{g} / \mathrm{mL}$ reliably predicted an AUC $>50 \mu \mathrm{g} \cdot \mathrm{h} / \mathrm{mL}$ [70], whereas Sobiak et al. [97] suggested that along with $\mathrm{MPA} \mathrm{AUC}_{0-12}>60 \mu \mathrm{g} \cdot \mathrm{h} / \mathrm{mL}, \mathrm{MPAC}_{\text {trough }}>3 \mu \mathrm{g} / \mathrm{mL}$ may be considered as an efficient one to avoid proteinuria recurrence. In this study, MPA $C_{\text {trough }}<2 \mu \mathrm{g} / \mathrm{mL}$ and lower fMPA were related with the risk of proteinuria recurrence. In a study by Kirpalani et al. [99], the authors calculated MPA AUC based on $\mathrm{C}_{\text {trough }}$ and found that in children with nephrotic syndrome, trough level monitoring may provide some information for MPA exposure if MMF administered in monotherapy. Moreover, Hibino et al. [100] suggested that MPA concentration $2 \mathrm{~h}$ after drug administration $\left(\mathrm{C}_{2}\right)$ is the most useful single parameter for estimating MPA pharmacokinetics in children with clinically stable nephrotic syndrome. They generated the equation: $\mathrm{AUC}_{0-12}=21.971+2.6059 \mathrm{C}_{2}$ and found that target $C_{2}$ was estimated at $10.8 \mu \mathrm{g} / \mathrm{mL}$ for $50 \mu \mathrm{g} \cdot \mathrm{h} / \mathrm{mL}$ of target $\mathrm{AUC}_{0-12}$ [100].

\subsubsection{TDM Based on Mycophenolic Acid Glucuronide (MPAG) and fMPA Pharmacokinetics}

Hui-Yen et al. [91] suggested that mycophenolic acid glucuronide (MPAG) might be used as a simple measure of MPA metabolism and adherence; they also suggested that MPAG may be a more accurate predictor of the likelihood of response to therapy with MMF in pediatric-onset lupus nephritis. The MPAG concentrations were therapeutic $(44.2 \pm 26.7 \mu \mathrm{g} / \mathrm{mL})$ in patients in complete remission and low $(29.88 \pm 22 \mu \mathrm{g} / \mathrm{mL})$ in patients not in complete remission, although the difference was not statistically significant.

Although unbound, free MPA (fMPA) is the pharmacologically active form of the drug, relatively small number of studies focus on fMPA analysis [116]. Smits et al. [76] tried to 
answer the question whether fMPA TDM might have any advantages over current practice of monitoring total MPA. The $\mathrm{fEC}_{50}$ value $(164.5 \mu \mathrm{L})$ provided an in vivo pharmacological insight into IMPDH inhibition, as its value was in accordance with the previously reported in vitro IMPDH inhibition parameters; however, it was much lower than the $\mathrm{EC}_{50}$ obtained from the analysis with total MPA $(0.97 \mathrm{mg} / \mathrm{mL})$. The authors stated that because only the fMPA is considered to exhibit the pharmacological effect, its parameters cannot be derived from the total MPA concentration despite good correlation between fMPA and total MPA $\left(r^{2}=0.85\right)$ [76]. Taking time and additional cost of ultrafiltration devices into account, the authors concluded that there was no clear advantage of the routine measurement of fMPA over the total MPA monitoring [76].

In a recent study of Liu et al. [116], who developed a simple and sensitive ultrafiltration and LC-MS/MS method for total and fMPA determination, the authors recommended close free drug monitoring and dose adjustments in pediatric patients with hypoproteinemia to prevent toxicity. The mean fMPA in pediatric renal transplant recipients was $0.89 \%$ (ranging from 0.62 to $1.25 \%$ ), and the authors indicated that the fMPA was small and concluded that plasma albumin level plays a major role in the variability of fMPA.

\subsubsection{TDM Based on Pharmacodynamics}

There has been still an ongoing discussion whether other biomarkers might be useful in MPA TDM. As MPA inhibits IMPDH activity, the results of such analysis may describe better the relation between MMF doses and MPA activity. There are some studies on IMPDH activity among children after renal transplantation $[76,79,80,117]$, with nephrotic syndrome [107], and with childhood-onset systemic lupus erythematosus [93]; however, no clear recommendations have been given [79]. Dong et al. [79] observed that high pretransplant IMPDH activity was associated with high rejection rate, whereas patients with a low IMPDH baseline value experienced more adverse events. The authors did not find any age-dependent differences in IMPDH activity in pediatric renal transplant recipients; however, African-American patients appeared to have a lower baseline IMPDH activity than Caucasian patients [79]. Rother et al. [117] found large interindividual variability of IMPDH activity in both healthy children and healthy adults and no gender- and age-related differences in median IMPDH activity $(82,61,83$ and $83 \mu \mathrm{mol} / \mathrm{s} / \mathrm{mol}$ AMP for healthy preschool children, school-age children, adolescents, and healthy adults, respectively). The authors found that despite a 1.9-fold increase in MPA exposure in the stable post-transplant period compared with the early post-transplant period, the corresponding IMPDH area under the activity-time curve $\left(\mathrm{AEC}_{0-12}\right)$ decreased by only $21 \%$. They concluded that this discrepancy might be explained by unchanged exposure to fMPA as they previously observed the increase of total MPA not fMPA in the first months post-transplant. Higher concentration $\mathrm{IC}_{50}$ leading to a half maximum IMPDH suppression (median, 5.4 and $4.4 \mathrm{mg} / \mathrm{L}$ for early post-transplant children and adolescents, respectively, median $9.6 \mathrm{mg} / \mathrm{L}$ for adolescents in the stable period) than previously described, found by Rother et al. [117] in children after renal transplantation, might be explained by the use of an improved assay for the determination of IMPDH activity. Higher $\mathrm{IC}_{50}$ corresponded with MPA $\mathrm{C}_{\max }$ rather than MPA predose levels. Fukuda et al. [80] observed high variability of IMPDH activity and lower mean pretransplant IMPDH activity $(6.4 \pm 4.6 \mathrm{nmol} / \mathrm{h} / \mathrm{mg}$ protein $)$ in children after renal transplantation than in adults. They described the overall relationship between MPA concentration and IMPDH activity using a direct inhibitory $E_{\max }$ model $\left(\mathrm{EC}_{50}=0.97 \mathrm{mg} / \mathrm{L}\right)$. In their opinion, pretransplant IMPDH activity may serve as an early marker to guide the initial level of MPA exposure required as IMPDH inhibition correlated well to MPA concentration.

\subsubsection{TDM Based on Pharmacogenetics}

There has been a discussion on the pharmacogenetic approach to MPA TDM. A recent study conducted by Krall et al. [74] showed that CYP3A5 and UGT1A9 genotyping in pediatric recipients might be useful and advisable to guide the dosing and monitoring of MPA 
and Tac in children that undergo kidney transplantation. Although no significant differences between MRP2 and UGT1A9 genotypes were observed regarding most MPA pharmacokinetic parameters $\left(C_{0}\right.$, dose, dose-normalized $\left.C_{0}\right)$, patients carrying the UGT1A9-275A allele had lower dose-normalized $\mathrm{AUC}_{0-12}$ than those carrying the UGT1A9-275T ancestral allele. In the study within pediatric renal transplant recipients, treated with MMF and Tac, Billing et al. [77] did not notice any impact of genetic variability of transporters or enzymes (CYP3A5, ABCB1, ABCG2, SLCO1B3, ABCC2, UGT1/2) on dose-adjusted MPA-AUC due to the low allele frequencies. Burckart et al. [83] proposed to include ABCC2 rs717620 polymorphisms in the pharmacogenomic analysis of outcomes after pediatric heart transplantation as they observed that the ABCC2 rs717620 AG and AA genotypes may be associated with improved, rather than poorer, rejection with hemodynamic compromise. Fukuda et al. [81] found that combined UGT1A9-440C $>$ T, UGT2B7-900A $>$ G, and MRP2-24T $>C$ polymorphisms might be important predictors of interindividual variability in MPA exposure in the pediatric population.

\subsubsection{Other Proposed Approaches of TDM}

Recently, Ye et al. [94] postulated that 25-hydroxyvitamin D levels were associated with MPA exposure levels and may serve as a potential indicator to optimize the exposure level of MPA during treatment.

\subsection{The Optimal Dosage Regimen}

For children after renal transplantation, the recommended starting dose of MMF is $1800 \mathrm{mg} / \mathrm{m}^{2} / \mathrm{d}$ when combined with CsA and $1200 \mathrm{mg} / \mathrm{m}^{2} / \mathrm{d}$ with Tac [118]. Rother et al. [117] raised the question whether dosing of MMF every $8 \mathrm{~h}$ might be more effective than the common twice a day regimen as they showed that IMPDH activity returned to baseline within 4-8 h of administration of MMF in children after renal transplantation. Krall et al. [74] recently published a study in which children after renal transplantation were treated with Tac and MMF at starting doses of $0.15 \mathrm{mg} / \mathrm{kg}$ twice per day and $800 \mathrm{mg} / \mathrm{m}^{2}$ twice per day, respectively. In a study conducted by Berger et al. [75], the initial dose of MMF was $400-600 \mathrm{mg} / \mathrm{m}^{2}$ orally every $12 \mathrm{~h}$ (up to a maximum of $2 \mathrm{~g}$ per day). The dose was subsequently modified to reach the target therapeutic range for MPA $C_{\text {trough }}$ and $\mathrm{AUC}_{0-12}$ as $1-3.5 \mathrm{mg} / \mathrm{L}$ and $30-60 \mathrm{mg} \cdot \mathrm{h} / \mathrm{L}$, respectively [75].

\subsection{Factors Affecting Serum Concentrations in TDM}

There are numerous factors influencing the pharmacokinetics of MPA, e.g., enterohepatic circulation, high degree of protein binding, drugs coadministered, time elapsed from the initiation of the therapy, and genetic polymorphism $[65,67,110]$. In pediatric renal transplant recipients, Smits et al. [76] observed large intrapatient and interpatient variability in binding percentages early post-transplant and at hospital discharge. The patients were treated with MMF, Tac, and corticosteroids. The binding profile became more stable over time; however, binding percentages $(85.6-91.9 \%)$ were significantly lower than those reported in other patient populations. The authors listed several possibilities of their observation, e.g., excessive albumin loss through the kidney, the presence of MPAG, endogenous compounds, and comedication could compete for binding sites, decreased binding of acidic drugs (such as MPA) to albumin in chronic kidney failure, surgical stress, and reported lower albumin production [76]. In a study conducted by Kirpalani et al. [99], the authors observed a correlation between apparent MPA clearance $(\mathrm{CL} / \mathrm{F})$ and serum albumin, microalbuminuria, proteinuria, triglycerides, and hematocrit and concluded that higher drug doses may be needed to achieve adequate MPA exposure to get patients into remission [99].

Some studies proved the differences in MPA pharmacokinetics according to the age of children. It was observed that pediatric renal transplant recipients were at a greater risk for underimmunosuppression at a younger age ( $<6$ years) due to faster clearance, even when dosing MMF per $\mathrm{m}^{2}$ body surface area [119]. Similarly, as in pediatric renal transplant 
recipients, Carlone et al. [88] found that children after allo-HSCT who were $<6$ years of age required a significantly higher initial MMF daily dose than older children. The difference was explained by greater drug clearance in younger children [88]. Nakaseko et al. [109] found in juvenile patients with autoimmune diseases that the actual measured MPA $\mathrm{AUC}_{0-12}$ and the $\mathrm{AUC}_{0-12}$ corrected for dose per body weight and time to reach maximum concentration $\left(\mathrm{C}_{\mathrm{max}}\right)$ were lower in young patients, whereas the $\mathrm{AUC}_{0-12}$ corrected for dose per body surface area and $C_{\max }$ were comparable among all the groups. Although Harnicar et al. [85] did not identify an age effect, they concluded that young children were potentially at special risk as patients $<16$ years of age had lower troughs over the 6-week period, as expected given their faster MMF metabolism. Kim et al. [84] indicated that for children $<10 \mathrm{~kg}$, higher doses may be required to achieve exposure similar to that in adults known to prevent acute GVHD.

Zhang et al. [85] also observed gender-related differences in pharmacokinetics. In pediatric patients after HSCT, MPA as well as MPAG plasma protein binding was significantly higher in boys compared to girls $(98.3 \% \pm 1.1 \%$ vs. $97.4 \% \pm 1.1 \%$ for MPA; $78.7 \% \pm 8.7 \%$ vs. $73.3 \% \pm 9.4 \%$ for MPAG). Consequently, lower percentages of unbound forms were observed in pediatric males than females $(1.7 \% \pm 1.1 \%$ vs. $2.6 \% \pm 1.1 \%$ for MPA; $21.3 \% \pm 8.7 \%$ vs. $26.7 \% \pm 9.4 \%$ for MPAG) [85].

One study described the differences in MMF dosing due to race. In children after heart transplantation, Siddiqi et al. [82] observed that higher MMF dosing was needed in AfricanAmerican pediatric heart transplant recipients $\left(702 \pm 235 \mathrm{mg} / \mathrm{m}^{2}\right.$ vs. $596 \pm 99 \mathrm{mg} / \mathrm{m}^{2}$ all other races) to achieve similar MPA $C_{\text {trough }}$.

The treatment duration is also not without significance. Windreich et al. [87] observed lower half-life and higher drug clearance in pediatric HCT recipients compared with stable pediatric renal transplant patients or adult transplant patients.

Drug-drug interactions which might have some implications for MPA TDM and have been described within the last decade concern sirolimus and nonsteroidal antiinflammatory drugs. The interaction between MMF and sirolimus prove the importance of TDM when switching concomitant medications [68]. Alvarez-Elías et al. [68] found that patients with elevated sirolimus concentrations are at risk for MMF toxicity, whereas patients with low sirolimus concentrations would have an even greater risk for rejection because of the effect of sirolimus on the MPA exposure; however, the mechanism for this drugdrug interaction remains unclear [68]. Fukuda et al. [95] found that concomitant intake of nonsteroidal anti-inflammatory drugs may lower enterohepatic recirculation of MPA possibly through inhibition of MRP2 transport of MPAG. MMF is frequently administered concomitantly with steroids and in children after renal transplantation, the target MPA $\mathrm{AUC}_{0-12}$ range is $30-60 \mathrm{mg} \cdot \mathrm{h} / \mathrm{L}$, it must be emphasized that for steroids free regimen, $34 \%$ higher dose-adjusted MPA AUC was observed compared to patients receiving steroids [77].

\subsection{The Dosing in Different Groups of Patients}

The initial MMF dose of $600 \mathrm{mg} / \mathrm{m}^{2}$ twice a day was administered in children after intestinal transplantation when cotreated with Tac and steroids [66]. The initial MMF dose of $600 \mathrm{mg} / \mathrm{m}^{2}$ twice a day was administered also in children after liver transplantation when coadministered with Tac or CsA [72].

MMF dosing in pediatric HCT has been primarily extrapolated from data in solid organ transplant recipients, and the optimal dosing of MMF in the HCT setting has not been clearly defined [87]. In children $<12$ years after double-unit cord blood transplantation, intensified dosing of $30 \mathrm{mg} / \mathrm{kg} /$ dose (nearly $900 \mathrm{mg} / \mathrm{m}^{2} /$ dose) to optimize MPA exposure was proposed [90]. In children after allo-HSCT, treated concomitantly with Tac, Militano et al. [84] demonstrated that MMF administered at a dose $900 \mathrm{mg} / \mathrm{m}^{2} /$ dose (maximum $1.5 \mathrm{~g} /$ dose) intravenously or orally in $8 \mathrm{~h}$ intervals was safe and associated with an improved risk of grade II-IV acute graft-versus-host disease (GVHD) as compared to $6 \mathrm{~h}$ intervals. In children after HSCT, other dosing was applied by Zhang et al. [85]. MMF was administered as a $2 \mathrm{~h}$ intravenous infusion at a dose of $15 \mathrm{mg} / \mathrm{kg}$ every $8 \mathrm{~h}$ 
concomitantly with Tac or CsA [85]. Moreover, Inagaki et al. [86] treated children steroidrefractory acute GVHD after HSCT with oral formulation of MMF at an initial median dose of $40 \mathrm{mg} / \mathrm{kg} /$ day, and the dose was increased by 1.5-2 times if manifestations of GVHD did not improve. The authors concluded that MMF was highly effective at higher doses (median maximum dose of $60 \mathrm{mg} / \mathrm{kg} /$ day) as they found no fatal toxicity as well as MMF-related infections. In pediatric-onset lupus nephritis, the daily dose of MMF was based on the renal transplant regimen of 20 to $30 \mathrm{mg} / \mathrm{kg}$ per dose or $600 \mathrm{mg} / \mathrm{m}^{2}$ per dose orally twice daily [91]. In a recent study by Chen et al. [92], in children with systemic lupus erythematosus, an initial MMF dose of $20-40 \mathrm{mg} / \mathrm{kg} / \mathrm{d}$ twice daily (maximum of $1.5 \mathrm{~g} / \mathrm{d}$ ) was administered in addition to prednisolone and hydroxychloroquine. In childhood-onset lupus erythematosus, Sagcal-Gironella et al. [93] found that weight-based MMF dosing was only moderately related to MPA exposure; therefore, weight-based MMF dosing did not appear to be useful in estimating the adequacy of MPA exposure. In children with stable idiopathic nephrotic syndrome, MMF was administered twice a day at doses $30-40 \mathrm{mg} / \mathrm{kg} /$ day (maximum dose of $1000 \mathrm{mg} /$ day) if coadministered with CsA [100]. Hibino et al. [100] suggested that children $<6$ years old require about twice the MMF dose per body weight that older children require, as the MPA exposure was lower in the youngest group. In children with frequently relapsing steroid-sensitive nephrotic syndrome and steroid-dependent nephrotic syndrome, the starting dose of MMF was 1000-1200 mg/m² BSA per day in two divided doses [70,101]. Interestingly, Hackl et al. [102] observed that significantly higher daily dosage of MMF administered to patients with relapses compared with those without relapses did not result in higher MPA exposure. In juvenile patients with autoimmune diseases, the staring MMF dose was $20 \mathrm{mg} / \mathrm{kg} /$ day, and it increased to around $30-40 \mathrm{mg} / \mathrm{kg} /$ day while monitoring safety [109].

The initial dose of MMF in children with Henoch-Schönlein purpura was $800-1200 \mathrm{mg} / \mathrm{m}^{2}$ BSA/day administered in two doses [108].

\subsection{Additional Information Useful for MPA TDM}

Apart from high variability in its pharmacokinetics, the other obstacle in comparing MPA concentrations between different studies are the determination methods. The golden standard is high-performance liquid chromatography (HPLC) method, which is time- and labor-consuming and requires qualified staff. Even more accurate and precise results are obtained using liquid chromatography with tandem mass spectrometry (LC-MS/MS) method. The second method for MPA determination is the immunoassay, which is faster and easier; however, the determined MPA concentrations are 5-40\% higher than those obtained using the HPLC method $[110,120,121]$. One must bear in mind this difference when comparing the results as in the literature both methods are used $[66,67,97,100,106]$.

The LC-MS/MS method was also applied to determine MPA and MPAG in saliva in few studies, but only two of them included pediatric patients [122,123]. Both authors showed a significant correlation between MPA concentrations in plasma and saliva and concluded that saliva might be a suitable matrix for MPA TDM in pediatric renal transplant recipients.

Recently, Almardini et al. [78] applied dried blood spot sampling to determine MPA concentration with HPLC method. The authors concluded that using dried blood spot was a convenient direct approach to assessing adherence in children after renal transplantation and has the potential to be introduced into routine practice.

In the literature, there are some studies on generic MMF; however, most of them concerned adults. González-Ramírez et al. [124] compared the innovator product (CellCept ${ }^{\circledR}$, Roche, Basel, Switzerland) and the generic (Tevacept ${ }^{\circledR}$, Teva Pharmaceuticals, North Wales, PA, USA) in children with end-stage renal disease who were on the waiting list for renal transplantation. Although an important interindividual variability in bioavailability for both MPA formulations was observed, the authors found individual values of AUC within the same range as well as no statistically significant differences in bioavailability parameters between formulations. Moreover, both formulations exhibited similar drug content 
and dissolution profiles [124]. The authors emphasized, however, that although the generic is a suitable formulation for immunosuppressive treatment in pediatric patients, their data did not demonstrate that CellCept ${ }^{\circledR}$ and Tevacept ${ }^{\circledR}$ are bioequivalent formulations in children, as a lack of significant differences in bioavailability parameters is not a proof of bioequivalence.

\section{Vancomycin (VAN)}

\subsection{Useful PK/PD Parameters}

VAN is a glycopeptide antibiotic with an activity against Gram-positive bacteria. It comprises the methicillin-resistant Staphylococcus aureus (MRSA). It exhibits a timedependent bactericidal effect, which means the drug's time is above the MIC. The activity is based on disrupting the cell wall synthesis via inhibiting the incorporation of monomers into peptidoglycan chains. It is recommended for skin infections, soft tissue infections, bacteremia, infective endocarditis, pneumonia, osteomyelitis, septic arthritis, meningitis, and septic thrombosis. It is widely prescribed for hospitalized children. The pharmacodynamic parameter that describes the effectiveness of the antibacterial activity the best is the AUC over MIC [125,126].

\subsection{Timing of Initial TDM and Target Concentration of VAN}

According to the consensus recommendation, the initial doses should be calculated basing on the actual body weight. Dose adjustment should be based on serum concentration. The $\mathrm{C}_{\text {trough }}$ should be reached before the fourth dose at steady state conditions. The $C_{\text {trough }}$ should be above $10 \mathrm{mg} / \mathrm{L}$ to avoid the development of $S$. aureus resistant strains. The TDM is advised for patients receiving aggressive dosing, with unstable renal function, and for patients with therapy courses longer than 3-5 days [127]. Fitzgerald et al. recommended the TDM of VAN after the first dose in the patients with cardiac arrest [128]. The MIC $\leq 1 \mathrm{mg} / \mathrm{L}$ is common for many MRSA strains, and the recommended $C_{\text {trough }}$ should be within the range of 15-20 mg/L. However, the administration of VAN every $12 \mathrm{~h}$ with dose $15 \mathrm{mg} / \mathrm{kg}$ is unlikely to produce the concentrations of 15-20 mg/L [127,129]. For seriously ill adult patients (pneumonia, sepsis, infective endocarditis) with MRSA infections, the loading dose of $25-30 \mathrm{mg} / \mathrm{kg}$ in up to $2-\mathrm{h}$ infusion with premedication of antihistamine drug is administered. The considered loading dose for seriously ill children is of $20-25 \mathrm{mg} / \mathrm{kg}$. The targeted AUC / MIC should be $>400$, and $\mathrm{C}_{\text {trough }}$ during the VAN concentration monitoring should be within the range of $15-20 \mathrm{mg} / \mathrm{L}$. These recommendations are valid for both pediatric and adult patients [130]. However, it is challenging because children have an increased renal clearance of VAN. It results in the $C_{\text {trough }}$ of $10-20 \mathrm{mg} / \mathrm{L}$, and higher doses must be administered to reach the goal concentration of $>10 \mathrm{mg} / \mathrm{L}$, which is recommended for MRSA treatment [125]. The IV dosing is $15 \mathrm{mg} / \mathrm{kg} /$ dose every six hours in children with invasive disease, bacteremia, infective endocarditis, prosthetic valve, pneumonia, osteomyelitis, septic arthritis, meningitis, brain abscess, spinal epidural abscess, subdural epynema, and septic thrombosis of cavernous or dural venous sinus. The antibiotic therapy may take even up to 6 weeks depending on the source of infection. The dose for adults is 15-20 mg/ kg/dose every 8-12 h. However, it should not exceed $2 \mathrm{~g}$ per dose. The dose is recommended for patients with normal renal function. VAN poorly permeates the cerebrospinal fluid $-1 \%$ for uninflamed and $5 \%$ for inflamed meninges. In this case, it is recommended to administer the loading dose of $15 \mathrm{mg} / \mathrm{kg}$ followed by the continuous infusion of 50-60 mg/ kg/day for patients with normal renal function [130].

\subsection{The Optimal Dosage Regimen}

Frymoyer et al. [131] performed a pharmacokinetic simulation in which $\mathrm{VAN}_{\text {trough }}$ of $7-10 \mathrm{mg} / \mathrm{L}$ at dose $15 \mathrm{mg} / \mathrm{kg}$ every $6 \mathrm{~h}$ (60 mg/kg/day) achieved the goal $\mathrm{AUC}_{0-24} / \mathrm{MIC} \geq 400$ at MIC $1 \mathrm{mg} / \mathrm{L}$ for MRSA. This target is easily achievable. Higher doses are not necessary. A similar conclusion was drawn by Le et al. [132], who observed that the $\mathrm{AUC}_{0-24} / \mathrm{MIC} \geq 400$, which corresponded with the $C_{\text {trough }}$ within $8-9 \mathrm{mg} / \mathrm{L}$, was achieved for the dosing 
regimen $60-70 \mathrm{mg} / \mathrm{kg} /$ day in $75 \%$ of patients. Higher doses than $70 \mathrm{mg} / \mathrm{kg} /$ day may be necessary for children between 1-2 years old with serum creatinine $0.2-0.4 \mathrm{mg} / \mathrm{dL}$. The doses higher than $80 \mathrm{mg} / \mathrm{kg}$ day should be administered cautiously. It was demonstrated that weight-adjusted VAN dosing regimen should be based on age, serum creatinine, and MIC of MRSA. The dosing interval $8 \mathrm{~h}$ achieved similar AUC/MIC target as for the dosing interval $6 \mathrm{~h}$. However, the longer time interval reduces the $\mathrm{C}_{\text {trough }}$ [132]. Meta-analysis performed by Moriyama et al. [133] proved that incidence of nephrotoxicity increased in the trough concentration $\geq 15 \mathrm{mg} / \mathrm{L}$. The concentrations $>10 \mathrm{mg} / \mathrm{L}$ allowed to attain of AUC values higher than $400 \mu \mathrm{g} \cdot \mathrm{h} / \mathrm{mL}$. The level of VAN $\geq 15 \mathrm{mg} / \mathrm{L}$ associated with kidney injury was also proved by Fiorito et. al. [134]. The necessity of the estimation of $\mathrm{AUC}_{0-24}$ parameter in children from intensive care units (ICU) confirmed the study conducted by Hahn et al. [135]. The patients with MRSA who required intensive ICU support had higher $\mathrm{AUC}_{0-24}$ and average AUC ( $\left(\mathrm{UCC}_{\mathrm{avg}}\right.$ ) than patients not needing the ICU support. The TDM in this group should be applied because basing only on serum creatinine measurements might not reflect VAN clearance. Clear correlation of VAN concentration with AUC does not reflect to the exposure of the drug for all pediatric patients. The best sampling to predict the values of AUC is at the end of infusion, 40-45 min after the infusion (in the distribution phase), and $12 \mathrm{~h}$ postinfusion or predose trough. The targeting trough levels in adult patients is simpler for clinicians. However, it is not such a simple case in children. Some children have a rapid elimination of VAN. It results in the necessity of the dose adjustment. The personalized medical treatment with the determination of AUC and MIC results in the successful therapy [136].

The dosing of vancomycin in the children with renal failure depended on the creatinine clearance. For the creatine clearance $40-60 \mathrm{~mL} / \mathrm{min}$ for children $<12$ years, the dosing of vancomycin is $15 \mathrm{mg} / \mathrm{kg}$ IV (q8h) and for children $\geq 12$ years- $10 \mathrm{mg} / \mathrm{kg}$ IV (q8h). When creatinine clearance is lower- $30-40 \mathrm{~mL} / \mathrm{min}$, the dosing interval changes from $\mathrm{q} 8 \mathrm{~h}$ to q12h. For creatinine clearance below $30 \mathrm{~mL} / \mathrm{min}$, the dosing interval is once a day [137].

The data concerning dosing of vancomycin in obese patients are lacking. In the meta-analysis performed by Khare et al. [138], higher vancomycin trough concentrations were found in overweight children or children with obesity. However, the heterogeneity of the published studies makes the clinical significance uncertain. The overweight and obesity may have an impact on pharmacokinetic parameters concerning distribution and elimination. The clinician should be aware that it may change the pharmacokinetic profile. In the case of adults, the dosing recommendations are clear-the dose of vancomycin must be adjusted to actual body weight [130].

\subsection{Factors Affecting Serum Concentrations in TDM}

The protein binding of VAN was approximately $50 \%$, and it may vary between the subjects [139]. Berthoin et al. conducted a study in which the free fraction $\left(f_{\mathrm{u}}\right)$ was $63.6 \pm 25.8 \%$ (median $70.2 \%$ ). The results comprised the range of $12-100 \%$. The $95 \%$ confidence interval was $57.3-69.9 \%$. A total percentage of $59 \%$ of values were outside the confidence interval [140]. De Cock et al. conducted a study of VAN protein binding in critically ill children. The unbound fraction $\left(f_{u}\right)$ varied between patients. The median value was $71.1 \%$ and demonstrated high variability. It ranged from $49.4 \%$ to $98.1 \%$. The observed median $C_{\text {trough }}$ was $6.7 \mathrm{mg} / \mathrm{L}$ [131]. Oyaert et al. conducted the study on the unbound concentration of VAN on four different patients' populations: pediatric and adults (hematology, intensive care, and orthopedics). The unbound fraction was significantly higher for children (81.3\%) than in adult patients. In hematology and intensive care populations, it amounted to ca. $61 \%$, and for the orthopedics population, it was slightly lower $(56.4 \%)$. For all investigated groups, high variability was observed, with the widest range observed for hematology patients (from 48.7 to 90.6\%) [141].

The interindividual variability could also be a result of a sample preconditioning. Stove et al. conducted a study in which the unbound fraction was analyzed in patients samples with ultrafiltration in $4{ }^{\circ} \mathrm{C}$ and $37^{\circ} \mathrm{C}$ and with equilibrium dialysis in $37^{\circ} \mathrm{C}$. The 
free drug fraction after ultrafiltration was $30.6 \%$ lower at $4{ }^{\circ} \mathrm{C}$ than for $37^{\circ} \mathrm{C}$. The results for equilibrium dialysis were similar to the ultrafiltration for $37^{\circ} \mathrm{C}$. VAN occurred to be stable when stored at $37^{\circ} \mathrm{C}$ for $24 \mathrm{~h}$. However, there were some limitations in this study, such as the $\mathrm{pH}$ not being adjusted, and the protocols were anonymized and some data (comedication, the VAN doses, renal function, and other patient characteristics) were not available. The model was based on the total protein concentration up to $68 \mathrm{~g} / \mathrm{L}$. It was in the lower values within the concentration range (64-83 g/L). Hypoalbuminemia is common in critically ill patients $[142,143]$.

A study on the ultrafiltration method was also conducted by Kees et al. The authors examined the influence of centrifugal force, temperature, and $\mathrm{pH}$ on protein binding. The higher centrifugation force $(10,000 \mathrm{~g}$ vs. $1000 \mathrm{~g})$ resulted in shorter time to obtain the satisfactory volume of filtrate. However, the $f_{\mathrm{u}}$ of VAN was much lower for high speed of centrifugation (44.7\% vs. $76.2 \%$ ). The increase in $\mathrm{pH}$ from 6.0 to 9.0 resulted in the increase in unbound fraction from $60 \%$ to $100 \%$. The observed $f_{\mathrm{u}}$ for $\mathrm{pH} 7.4$ was $77 \%$, and for $\mathrm{pH} 8.0$, it was $82 \%$. The increase in the $\mathrm{pH}$-dependent protein binding for VAN confirmed the results obtained by Chen et al. [144]. The increase in the temperature resulted also in the increase of the $f_{\mathfrak{u}}$. For the temperature range $4{ }^{\circ} \mathrm{C}-37^{\circ} \mathrm{C}$, the following increase from $57 \%$ to $80 \%$ was observed. However, the difference in $f_{\mathrm{u}}$ between the room temperature $\left(25^{\circ} \mathrm{C}\right)$ and $37^{\circ} \mathrm{C}$ was not significant (75\% vs. $\left.80 \%\right)$ [145].

The correct sampling procedure is important when considered the effectiveness of TDM. The venipuncture or capillary fingerstick might be considered painful and stressful. Lichlitter et al. [146] conducted a study in which the blood samples were collected by existing central venous catheter (CVC) and peripheral intravenous catheter (PIV). The measurements were conducted for VAN and tobramycin in pediatric patients. A good correlation was found between the VAN $C_{\text {trough }}$ and random tobramycin concentration in serum for existing CVC and PIV between the concentrations obtained via peripheral venipuncture or capillary fingerstick. The limitation of the study was the fact that the correlation was found only for the above-mentioned kind of concentrations. However, the limitation of the number of venipunctures leads to the improvement of the satisfaction of patients as well as their families and medical staff.

\subsection{The Dosing in Different Groups of Patients}

McKamy et al. investigated the incidence of VAN-associated nephrotoxicity in children [147]. It occurred that the recommended $C_{\text {trough }} \geq 15 \mathrm{mg} / \mathrm{L}$ may be associated with a higher incidence of nephrotoxicity. The doses necessary to maintain $C_{\text {trough }}$ on the previously mentioned level should be $50-60 \mathrm{mg} / \mathrm{kg} /$ day. The incidents of nephrotoxicity necessitated the decrease of VAN doses. Furosemide, a loop diuretic, is commonly used in the ICU. Its administration may lead to dehydration, which increase the risk of nephrotoxicity. The patients with coadministration of VAN and furosemide should be closely monitored. The aggressive dosing of VAN could also lead to drug accumulation throughout therapy. A study performed by De Cock et al. on the pediatric patients from the ICU showed that the total concentration of VAN $7 \mathrm{mg} / \mathrm{L}$ corresponded with AUC/MIC $>400$ [148]. A study conducted by Giachetto et al. showed that critically ill pediatric patients on the ICU may require higher doses of VAN. It can be caused by the positive water balance and high volume of distribution. In this case, the recommended doses cause the lower concentrations, and the goal value of $\mathrm{AUC}_{24} / \mathrm{MIC}>400$ ratio will not be achieved. In this case, higher loading doses are recommended $(18-24 \mathrm{mg} / \mathrm{kg})$. The dosage should be adjusted to individual parameters [149]. Dolan et al. investigated the application of loading dose in pediatric patients. The recommended loading dose was $20-25 \mathrm{mg} / \mathrm{kg}$. It was determined on the extrapolation of the loading dose for adults which was $25-30 \mathrm{mg} / \mathrm{kg}$ (actual body weight). The application of the loading dose was at the discretion of the clinician. The application of the loading dose improved the achievement of therapeutic concentrations; however, for the majority of patients, after receiving the loading dose, the concentrations were still subtherapeutic $[130,150]$. 
The meta-analysis conducted by da Silva Alves et al. proved that a daily dose of VAN below $60 \mathrm{mg} / \mathrm{kg} /$ day was insufficient to achieve the AUC/MIC ratio $>400$ or $C_{\text {trough }}$ $10-20 \mathrm{mg} / \mathrm{L}$. The initial dose of VAN $40 \mathrm{mg} / \mathrm{kg} /$ day may be unsatisfactory and associated with subtherapy. The dose $\geq 60 \mathrm{mg} / \mathrm{kg} /$ day provides effective plasma concentrations [151]. Tkachuk et al. conducted the meta-analysis on the relationship between VAN trough and AUC/MIC ratio for different pediatric hospitalized patients' groups: general patients, cardiothoracic surgery patients, oncology patients, critically ill, and adolescents. The conducted meta-analysis for general hospitalized patients showed that the troughs between 6-10 mg/L were adequate to reach the AUC/MIC ratio above 400 for MIC $1 \mathrm{mg} / \mathrm{L}$ [126]. According to a study conducted by Benefield et al. [152] on cardiothoracic patients, the applied dosage was $20 \mathrm{mg} / \mathrm{kg} /$ dose every $8 \mathrm{~h}$. Compared with the control group, the cardiothoracic surgery (CTS) patients were characterized by higher $\mathrm{C}_{\text {trough }}(18.4 \mathrm{vs} .8 .8 \mathrm{mg} / \mathrm{L})$. The $C_{\text {trough }}$ within the range $10-20 \mathrm{mg} / \mathrm{L}$ were observed at $>50 \%$ CTS. It was also noted that acute kidney disease developed in $25.9 \%$ of CTS patients. In the control group, it was not observed. Three other trials noted that in critically ill children, acute kidney injury (AKI) developed [153-155]. The incidence of AKI was from $5.4 \%$ to $17.2 \%$. In the study conducted by Moffet et al. [153], the VAN-associated AKI occurred in $7.2 \%$ of patients. The incidence was associated with a critical illness. A retrospective cohort study conducted by Cies et al. [154] suggested no statistically significant difference in the incidence of induced nephrotoxicity with VAN in patients from pediatric ICU with VAN $C_{\text {trough }} 15-20 \mathrm{mg} / \mathrm{L}$ at patients with a concentration lower than $15 \mathrm{mg} / \mathrm{L}$. The incidence of nephrotoxicity may be associated with the duration of the VAN treatment and concomitant use of vasopressors. In a retrospective study conducted by Hays et al. [155], the VAN-associated AKI developed at $40 \%$ critically ill adolescent and young adult patients. The risk of incidence of AKI is increasing in the patients with high VAN trough levels, the concomitant use of nephrotoxic agents, and vasopressor therapy. Patients that underwent the surgical procedure were also at risk. Lanke et al. [156] conducted a retrospective study on adolescents (12-18 years old). The analysis proved that $C_{\text {trough }} 10-12.5 \mathrm{mg} / \mathrm{L}$ provided the $\mathrm{AUC}_{0-24} / \mathrm{MIC}$ ratio $\geq 400$. The observed MIC was $\leq 1 \mathrm{mg} / \mathrm{L}$, which implies that the effective $C_{\text {trough }}$ for adolescents are lower than for adults.

The other group in which the TDM should be introduced is children with cardiac arrest. This group is vulnerable to infections. Sepsis-associated cardiac arrest is a factor that worsens the chances of survival in patients [157]. VAN is excreted with urine, and the cardiac arrest led to the decrease of renal function and therapeutic hypothermia. Zane et al. observed that patients with normal renal function and treated with hypothermia experienced up to $25 \%$ reduction in the clearance of VAN when compared to the patients with normothermia. A reduction in clearance up to $84 \%$ was observed in patients who had reduced renal function and were treated with therapeutic hypothermia. The reduction in renal clearance results in the reduction of VAN clearance. That makes the TDM of VAN at patients with cardiac arrest treated with therapeutic hypothermia necessary [158].

Fitzgerald et al. conducted a study on children with AKI after cardiac arrest [128]. In the study, in the patients with AKI, the observed initial concentrations of VAN were higher than in those without AKI. It was a result of a lower estimated glomerular filtration rate. The $C_{\text {trough }}$ should not be used instead of AUC to avoid the toxicity and estimate the antibiotic's effect on children with cardiac arrest. $C_{\text {trough }}$ in critically ill children may be found unreliable predictors of AUC, especially when renal dysfunction is observed. It makes more frequent TDM necessary, even after the first dose in all patients treated with VAN after cardiac arrest [128].

\section{Conclusions}

Recently, IFIs incidence has increased in the pediatric population, parallel with the increasing number of patients undergoing solid organ and bone marrow transplantation and those receiving chemotherapy and long-term immunosuppression. Despite sufficient care, mortality due to IFIs still remains unacceptably high. One of the possible causes of 
these failures is inadequate exposure to VCZ. Unfortunately, still little is known about the PK of VCZ. VCZ TDM should be routinely performed in this population to maximize the treatment effect. Large prospective studies with children are needed to further provide important information on PK VCZ and guide dosing to achieve successful treatment for pediatric patients.

Defining the target values for MPA TDM in pediatric patients is necessary for efficient treatment. Clear recommendations should be given for each of MMF treatment indication. TDM in the case of MPA is going to be still of major interest as MPA might be administered as anticancer drug due to its molecular mechanism of action: induction of apoptosis, induction of cell cycle arrest, and alteration of tumor microenvironment [159]. Moreover, there are few new immunosuppressive drugs under development for the transplant field, it is likely that MPA will continue to be prescribed on a large scale in the upcoming years [160].

The analyzed literature confirmed the necessity of TDM for VAN. The changes in elimination might be caused by the illness or the coadministration of the other drugs. The impact on water balance, elimination, and distribution may result in too high or low VAN concentration. It may have serious clinical consequences that could lead to serious adverse effects.

Author Contributions: Conceptualization, M.R.; methodology, M.R., J.S. and A.C.; investigation, M.R., J.S. and A.C.; resources, M.R., J.S. and A.C.; data curation, M.R., J.S. and A.C.; writing-original draft preparation, M.R.; writing-review and editing, M.R., J.S. and A.C.; supervision, A.C. All authors have read and agreed to the published version of the manuscript.

Funding: The study did not receive any relevant funding.

Institutional Review Board Statement: Not applicable.

Informed Consent Statement: Not applicable.

Data Availability Statement: The data presented in this study are available on request from the corresponding author. The data are not publicly available due to privacy restrictions.

Conflicts of Interest: The authors declare no conflict of interest.

\section{References}

1. Karlsson, M.O.; Lutsar, I.; Milligan, P.A. Population Pharmacokinetic Analysis of Voriconazole Plasma Concentration Data from Pediatric Studies. Antimicrob. Agents Chemother. 2009, 53, 935-944. [CrossRef] [PubMed]

2. Liu, L.; Zhou, X.; Wu, T.; Jiang, H.; Yang, S.; Zhang, Y. Dose optimisation of voriconazole with therapeutic drug monitoring in children: A single-centre experience in China. Int. J. Antimicrob. Agents 2017, 49, 483-487. [CrossRef] [PubMed]

3. Bartelink, I.H.; Wolfs, T.; Jonker, M.; De Waal, M.; Egberts, T.C.G.; Ververs, T.T.; Boelens, J.J.; Bierings, M. Highly Variable Plasma Concentrations of Voriconazole in Pediatric Hematopoietic Stem Cell Transplantation Patients. Antimicrob. Agents Chemother. 2012, 57, 235-240. [CrossRef] [PubMed]

4. Kadam, R.S.; Van Den Anker, J.N. Pediatric Clinical Pharmacology of Voriconazole: Role of Pharmacokinetic/Pharmacodynamic Modeling in Pharmacotherapy. Clin. Pharmacokinet. 2016, 55, 1031-1043. [CrossRef]

5. $\quad$ Lempers, V.J.; Meuwese, E.; Mavinkurve-Groothuis, A.M.; Henriet, S.; Van Der Sluis, I.M.; Hanff, L.M.; Warris, A.; Koch, B.C.P.; Brüggemann, R.J. Impact of dose adaptations following voriconazole therapeutic drug monitoring in pediatric patients. Med Mycol. 2019, 57, 937-943. [CrossRef]

6. Knight-Perry, J.; Jennissen, C.; Long, S.E.; Hage, S.; DeFor, T.E.; Chan, W.T.; Fisher, J.; Kirstein, M.N.; Smith, A.R. A phase I dose finding study of intravenous voriconazole in pediatric patients undergoing hematopoietic cell transplantation. Bone Marrow Transplant. 2019, 55, 955-964. [CrossRef]

7. Yousefian, S.; Dastan, F.; Marjani, M.; Tabarsi, P.; Barati, S.; Shahsavari, N.; Kobarfard, F. Determination of Voriconazole Plasma Concentration by HPLC Technique and Evaluating Its Association with Clinical Outcome and Adverse Effects in Patients with Invasive Aspergillosis. Can. J. Infect. Dis. Med Microbiol. 2021, 2021, 5497427. [CrossRef]

8. Kato, K.; Nagao, M.; Yamamoto, M.; Matsumura, Y.; Takakura, S.; Fukuda, K.; Ichiyama, S. Oral administration and younger age decrease plasma concentrations of voriconazole in pediatric patients. J. Infect. Chemother. 2016, 22, 27-31. [CrossRef]

9. Andes, D.; Marchillo, K.; Stamstad, T.; Conklin, R. In Vivo Pharmacokinetics and Pharmacodynamics of a New Triazole, Voriconazole, in a Murine Candidiasis Model. Antimicrob. Agents Chemother. 2003, 47, 3165-3169. [CrossRef] 
10. Wang, T.; Xie, J.; Wang, Y.; Zheng, X.; Lei, J.; Wang, X.; Dong, H.; Yang, Q.; Chen, L.; Xing, J.; et al. Pharmacokinetic and Pharmacodynamic Properties of Oral Voriconazole in Patients with Invasive Fungal Infections. Pharmacother. J. Hum. Pharmacol. Drug Ther. 2015, 35, 797-804. [CrossRef]

11. Soler-Palacín, P.; Frick, M.A.; Martín-Nalda, A.; Lanaspa, M.; Pou, L.; Roselló, E.; de Heredia, C.D.; Figueras, C. Voriconazole drug monitoring in the management of invasive fungal infection in immunocompromised children: A prospective study. J. Antimicrob. Chemother. 2011, 67, 700-706. [CrossRef]

12. Faghihi, T.; Tiihonen, M. Voriconazole Therapeutic Drug Monitoring: How to Adjust the Dose in Pediatrics? Iran. J. Pediatr. 2021, 31, e111582. [CrossRef]

13. John, J.; Loo, A.; Mazur, S.; Walsh, T.J. Therapeutic drug monitoring of systemic antifungal agents: A pragmatic approach for adult and pediatric patients. Expert Opin. Drug Metab. Toxicol. 2019, 15, 881-895. [CrossRef]

14. Jeans, A.R.; Howard, S.J.; Al-Nakeeb, Z.; Goodwin, J.; Gregson, L.; Warn, P.A.; Hope, W.W. Combination of Voriconazole and Anidulafungin for Treatment of Triazole-Resistant Aspergillus fumigatus in anIn VitroModel of Invasive Pulmonary Aspergillosis. Antimicrob. Agents Chemother. 2012, 56, 5180-5185. [CrossRef]

15. Troke, P.F.; Hockey, H.P.; Hope, W.W. Observational Study of the Clinical Efficacy of Voriconazole and Its Relationship to Plasma Concentrations in Patients. Antimicrob. Agents Chemother. 2011, 55, 4782-4788. [CrossRef]

16. Ashbee, H.R.; Barnes, R.A.; Johnson, E.M.; Richardson, M.; Gorton, R.; Hope, W. Therapeutic drug monitoring (TDM) of antifungal agents: Guidelines from the British Society for Medical Mycology. J. Antimicrob. Chemother. 2013, 69, 1162-1176. [CrossRef]

17. Moriyama, B.; Obeng, A.O.; Barbarino, J.; Penzak, S.R.; Henning, S.A.; Scott, S.; Agundez, J.; Wingard, J.R.; McLeod, H.L.; Klein, T.E.; et al. Clinical Pharmacogenetics Implementation Consortium (CPIC) Guidelines for CYP2C19 and Voriconazole Therapy. Clin. Pharmacol. Ther. 2016, 102, 45-51. [CrossRef]

18. Jin, H.; Wang, T.; Falcione, B.A.; Olsen, K.M.; Chen, K.; Tang, H.; Hui, J.; Zhai, S. Trough concentration of voriconazole and its relationship with efficacy and safety: A systematic review and meta-analysis. J. Antimicrob. Chemother. 2016, 71, 1772-1785. [CrossRef]

19. Dolton, M.J.; Ray, J.E.; Chen, S.C.-A.; Ng, K.; Pont, L.; McLachlan, A.J. Multicenter Study of Voriconazole Pharmacokinetics and Therapeutic Drug Monitoring. Antimicrob. Agents Chemother. 2012, 56, 4793-4799. [CrossRef]

20. Hu, L.; Dai, T.-T.; Zou, L.; Li, T.-M.; Ding, X.-S.; Yin, T. Therapeutic Drug Monitoring of Voriconazole in Children from a Tertiary Care Center in China. Antimicrob. Agents Chemother. 2018, 62, e00955-18. [CrossRef]

21. Ruiz, J.; Gordon, M.; Villarreal, E.; Peruccioni, M.; Marqués, M.R.; Poveda-Andrés, J.L.; Castellanos-Ortega, Á.; Ramirez, P. Impact of voriconazole plasma concentrations on treatment response in critically ill patients. J. Clin. Pharm. Ther. 2019, 44, 572-578. [CrossRef]

22. Luong, M.-L.; Al-Dabbagh, M.; Groll, A.H.; Racil, Z.; Nannya, Y.; Mitsani, D.; Husain, S. Utility of voriconazole therapeutic drug monitoring: A meta-analysis. J. Antimicrob. Chemother. 2016, 71, 1786-1799. [CrossRef]

23. Wang, T.; Zhu, H.; Sun, J.; Cheng, X.; Xie, J.; Dong, H.; Chen, L.; Wang, X.; Xing, J.; Dong, Y. Efficacy and safety of voriconazole and CYP2C19 polymorphism for optimised dosage regimens in patients with invasive fungal infections. Int. J. Antimicrob. Agents 2014, 44, 436-442. [CrossRef]

24. Neely, M.; Rushing, T.; Kovacs, A.; Jelliffe, R.; Hoffman, J. Voriconazole Pharmacokinetics and Pharmacodynamics in Children. Clin. Infect. Dis. 2010, 50, 27-36. [CrossRef]

25. Choi, S.-H.; Lee, S.-Y.; Hwang, J.-Y.; Lee, S.H.; Yoo, K.H.; Sung, K.W.; Koo, H.H.; Kim, Y.-J. Importance of voriconazole therapeutic drug monitoring in pediatric cancer patients with invasive aspergillosis. Pediatr. Blood Cancer 2012, 60, 82-87. [CrossRef]

26. Kang, H.M.; Lee, H.J.; Cho, E.Y.; Yu, K.-S.; Lee, H.; Lee, J.W.; Kang, H.J.; Park, K.D.; Shin, H.Y.; Choi, E.H. The Clinical Significance of Voriconazole Therapeutic Drug Monitoring in Children With Invasive Fungal Infections. Pediatr. Hematol. Oncol. 2015, 32, 557-567. [CrossRef]

27. Hanai, Y.; Hamada, Y.; Kimura, T.; Matsumoto, K.; Takahashi, Y.; Fujii, S.; Nishizawa, K.; Takesue, Y. Optimal trough concentration of voriconazole with therapeutic drug monitoring in children: A systematic review and meta-analysis. J. Infect. Chemother. 2020, 27, 151-160. [CrossRef]

28. Spriet, I.; Cosaert, K.; Renard, M.; Uyttebroeck, A.; Meyts, I.; Proesmans, M.; Meyfroidt, G.; De Hoon, J.; Verbesselt, R.; Willems, L. Voriconazole plasma levels in children are highly variable. Eur. J. Clin. Microbiol. Infect. Dis. 2010, 30, 283-287. [CrossRef]

29. Boast, A.; Curtis, N.; Cranswick, N.; Gwee, A. Voriconazole dosing and therapeutic drug monitoring in children: Experience from a paediatric tertiary care centre. J. Antimicrob. Chemother. 2016, 71, 2031-2036. [CrossRef]

30. Li, H.; Li, M.; Yan, J.; Gao, L.; Zhou, L.; Wang, Y.; Li, Q.; Wang, J.; Chen, T.; Wang, T.; et al. Voriconazole therapeutic drug monitoring in critically ill patients improves efficacy and safety of antifungal therapy. Basic Clin. Pharmacol. Toxicol. 2020, 127, 495-504. [CrossRef]

31. Gerin, M.; Mahlaoui, N.; Elie, C.; Lanternier, F.; Bougnoux, M.-E.; Blanche, S.; Lortholary, O.; Jullien, V. Therapeutic Drug Monitoring of Voriconazole After Intravenous Administration in Infants and Children With Primary Immunodeficiency. Ther. Drug Monit. 2011, 33, 464-466. [CrossRef] [PubMed]

32. Friberg, L.E.; Ravva, P.; Karlsson, M.O.; Liu, P. Integrated Population Pharmacokinetic Analysis of Voriconazole in Children, Adolescents, and Adults. Antimicrob. Agents Chemother. 2012, 56, 3032-3042. [CrossRef] [PubMed] 
33. Zane, N.R.; Thakker, D.R. A Physiologically Based Pharmacokinetic Model for Voriconazole Disposition Predicts Intestinal First-pass Metabolism in Children. Clin. Pharmacokinet. 2014, 53, 1171-1182. [CrossRef] [PubMed]

34. Tucker, L.; Higgins, T.; Egelund, E.F.; Zou, B.; Vijayan, V.; Peloquin, C.A. Voriconazole Monitoring in Children with Invasive Fungal Infections. J. Pediatr. Pharmacol. Ther. 2015, 20, 17-23. [CrossRef]

35. Mori, M.; Fukushima, K.; Miharu, M.; Goto, H.; Yoshida, M.; Shoji, S. A retrospective analysis of voriconazole pharmacokinetics in Japanese pediatric and adolescent patients. J. Infect. Chemother. 2013, 19, 174-179. [CrossRef]

36. Zembles, T.N.; Thompson, N.E.; Havens, P.L.; Kaufman, B.A.; Huppler, A.R. An Optimized Voriconazole Dosing Strategy to Achieve Therapeutic Serum Concentrations in Children Younger than 2 Years Old. Pharmacother. J. Hum. Pharmacol. Drug Ther. 2016, 36, 1102-1108. [CrossRef]

37. Chen, J.; Chan, C.; Colantonio, D.; Seto, W. Therapeutic Drug Monitoring of Voriconazole in Children. Ther. Drug Monit. 2012, 34, 77-84. [CrossRef]

38. Doby, E.H.; Benjamin, D.K.; Blaschke, A.J.; Ward, R.M.; Pavia, A.T.; Martin, P.L.; Driscoll, T.A.; Cohen-Wolkowiez, M.; Moran, C. Therapeutic Monitoring of Voriconazole in Children Less Than Three Years of Age: A Case Report and Summary of Voriconazole Concentrations for Ten Children. Pediatr. Infect. Dis. J. 2012, 31, 632-635. [CrossRef]

39. Allegra, S.; Fatiguso, G.; De Francia, S.; Favata, F.; Pirro, E.; Carcieri, C.; De Nicolò, A.; Cusato, J.; Di Perri, G.; D’Avolio, A. Therapeutic drug monitoring of voriconazole for treatment and prophylaxis of invasive fungal infection in children: Voriconazole Therapeutic Drug Monitoring in Paediatrics. Br. J. Clin. Pharmacol. 2017, 84, 197-203. [CrossRef]

40. Zhao, Y.-C.; Zou, Y.; Tang, D.; Xiao, C.-L.; Xiao, Y.-W.; Wang, F.; Zhang, B.-K.; Xiang, D.-X.; Yu, F.; Yan, M. Possibly Appropriate Maintenance Dose of Voriconazole in Pediatric Patients: A Single Center Observational Study. Available online: https: / / assets.researchsquare.com/files / rs-222933/v2/ebdd07af-2ef9-46de-8730-235df3de207d.pdf?c=1631885086 (accessed on 10 January 2021).

41. Duehlmeyer, S.; Klockau, C.; Yu, D.; Rouch, J. Characterization of Therapeutic Drug Monitoring Practices of Voriconazole and Posaconazole at a Pediatric Hospital. J. Pediatr. Pharmacol. Ther. 2021, 26, 26-32. [CrossRef]

42. Valle-T-Figueras, J.; Miró, B.R.; Carabante, M.B.; Díaz-De-Heredia, C.; Bofarull, J.V.; Mendoza-Palomar, N.; Martín-Gómez, M.; Soler-Palacín, P. Voriconazole Use in Children: Therapeutic Drug Monitoring and Control of Inflammation as Key Points for Optimal Treatment. J. Fungi 2021, 7, 456. [CrossRef]

43. Narita, A.; Muramatsu, H.; Sakaguchi, H.; Doisaki, S.; Tanaka, M.; Hama, A.; Shimada, A.; Takahashi, Y.; Yoshida, N.; Matsumoto, K.; et al. Correlation of CYP2C19 Phenotype With Voriconazole Plasma Concentration in Children. J. Pediatr. Hematol. 2013, 35, e219-e223. [CrossRef]

44. Lee, J.; Ng, P.; Hamandi, B.; Husain, S.; Lefebvre, M.J.; Battistella, M. Effect of Therapeutic Drug Monitoring and Cytochrome P450 2C19 Genotyping on Clinical Outcomes of Voriconazole: A Systematic Review. Ann. Pharmacother. 2020, 55, 509-529. [CrossRef]

45. Miller, M.A.; Lee, Y.M. Applying Pharmacogenomics to Antifungal Selection and Dosing: Are We There Yet? Curr. Fungal Infect. Rep. 2020, 14, 63-75. [CrossRef]

46. Moriyama, B.; Kadri, S.S.; Henning, S.A.; Danner, R.L.; Walsh, T.J.; Penzak, S.R. Therapeutic Drug Monitoring and Genotypic Screening in the Clinical Use of Voriconazole. Curr. Fungal Infect. Rep. 2015, 9, 74-87. [CrossRef]

47. Obeng, A.O.; Egelund, E.F.; Alsultan, A.; Peloquin, C.A.; Johnson, J.A. CYP2C19 Polymorphisms and Therapeutic Drug Monitoring of Voriconazole: Are We Ready for Clinical Implementation of Pharmacogenomics? Pharmacother. J. Hum. Pharmacol. Drug Ther. 2014, 34, 703-718. [CrossRef]

48. Hicks, J.K.; Quilitz, R.E.; Komrokji, R.S.; Kubal, T.E.; Lancet, J.E.; Pasikhova, Y.; Qin, D.; So, W.; Caceres, G.; Kelly, K.; et al. Prospective CYP2C19-Guided Voriconazole Prophylaxis in Patients with Neutropenic Acute Myeloid Leukemia Reduces the Incidence of Subtherapeutic Antifungal Plasma Concentrations. Clin. Pharmacol. Ther. 2019, 107, 563-570. [CrossRef]

49. Teusink, A.; Vinks, A.; Zhang, K.; Davies, S.; Fukuda, T.; Lane, A.; Nortman, S.; Kissell, D.; Dell, S.; Filipovich, A.; et al. Genotype-Directed Dosing Leads to Optimized Voriconazole Levels in Pediatric Patients Receiving Hematopoietic Stem Cell Transplantation. Biol. Blood Marrow Transplant. 2015, 22, 482-486. [CrossRef]

50. Luo, X.; Li, T.; Hu, L.; Liu, S.; Zhao, H.; Zhang, J.; Feng, Y.; Huang, L. Differential effects of C-reactive protein levels on voriconazole metabolism at three age groups in allogeneic hematopoietic cell transplant recipients. J. Chemother. 2020, 33, 95-105. [CrossRef]

51. Ter Avest, M.; Veringa, A.; van den Heuvel, E.R.; Kosterink, J.G.W.; Schölvinck, E.H.; Tissing, W.J.E.; Alffenaar, J.C. The effect of inflammation on voriconazole trough concentrations in children: Letter to the Editor. Br. J. Clin. Pharmacol. 2016, 83, 678-680. [CrossRef]

52. Vanstraelen, K.; Wauters, J.; Vercammen, I.; de Loor, H.; Maertens, J.; Lagrou, K.; Annaert, P.; Spriet, I. Impact of Hypoalbuminemia on Voriconazole Pharmacokinetics in Critically Ill Adult Patients. Antimicrob. Agents Chemother. 2014, 58, 6782-6789. [CrossRef]

53. Resztak, M.; Kosicka, K.; Zalewska, P.; Krawiec, J.; Główka, F.K. Determination of total and free voriconazole in human plasma: Application to pharmacokinetic study and therapeutic monitoring. J. Pharm. Biomed. Anal. 2019, 178, 112952. [CrossRef]

54. Driscoll, T.A.; Frangoul, H.; Nemecek, E.R.; Murphey, D.K.; Yu, L.C.; Blumer, J.; Krance, R.A.; Baruch, A.; Liu, P. Comparison of Pharmacokinetics and Safety of Voriconazole Intravenous-to-Oral Switch in Immunocompromised Adolescents and Healthy Adults. Antimicrob. Agents Chemother. 2011, 55, 5780-5789. [CrossRef]

55. Brüggemann, R.J.M.; van der Linden, J.W.M.; Verweij, P.E.; Burger, D.M.; Warris, A. Impact of Therapeutic Drug Monitoring of Voriconazole in a Pediatric Population. Pediatr. Infect. Dis. J. 2011, 30, 533-534. [CrossRef] 
56. Pieper, S.; Kolve, H.; Gumbinger, H.G.; Goletz, G.; Würthwein, G.; Groll, A.H. Monitoring of voriconazole plasma concentrations in immunocompromised paediatric patients. J. Antimicrob. Chemother. 2012, 67, 2717-2724. [CrossRef]

57. Zhao, Y.; Hou, J.; Xiao, Y.; Wang, F.; Zhang, B.; Zhang, M.; Jiang, Y.; Li, J.; Gong, G.; Xiang, D.; et al. Predictors of Voriconazole Trough Concentrations in Patients with Child-Pugh Class C Cirrhosis: A Prospective Study. Antibiotics 2021, 10, 1130. [CrossRef]

58. Wang, T.; Yan, M.; Tang, D.; Xue, L.; Zhang, T.; Dong, Y.; Zhu, L.; Wang, X.; Dong, Y. Therapeutic drug monitoring and safety of voriconazole therapy in patients with Child-Pugh class B and C cirrhosis: A multicenter study. Int. J. Infect. Dis. 2018, 72, 49-54. [CrossRef]

59. Lin, X.-B.; Huang, F.; Tong, L.; Xia, Y.-Z.; Wu, J.-J.; Li, J.; Hu, X.-G.; Liang, T.; Liu, X.-M.; Zhong, G.-P.; et al. Pharmacokinetics of intravenous voriconazole in patients with liver dysfunction: A prospective study in the intensive care unit. Int. J. Infect. Dis. 2020, 93, 345-352. [CrossRef]

60. Li, X.; Li, W.; Li, M.; Zhang, Z.; Liu, S.; Chen, Z. Correlation between enzyme multiplied immunoassay technique and highperformance liquid chromatography in the quantification of voriconazole in a paediatric population. Scand. J. Clin. Lab. Investig. 2021, 81, 121-126. [CrossRef]

61. Mei, H.; Hu, X.; Wang, J.; Wang, R.; Cai, Y. Determination of voriconazole in human plasma by liquid chromatography-tandem mass spectrometry and its application in therapeutic drug monitoring in Chinese patients. J. Int. Med Res. 2019, 48, 1-10. [CrossRef] [PubMed]

62. Baietto, L.; D’Avolio, A.; Marra, C.; Simiele, M.; Cusato, J.; Pace, S.; Ariaudo, A.; DE Rosa, F.G.; Di Perri, G. Development and validation of a new method to simultaneously quantify triazoles in plasma spotted on dry sample spot devices and analysed by HPLC-MS. J. Antimicrob. Chemother. 2012, 67, 2645-2649. [CrossRef] [PubMed]

63. Badiee, P.; Hashemizadeh, Z.; Montaseri, H. Therapeutic Drug Monitoring of Voriconazole: Comparison of Bioassay with High-Performance Liquid Chromatography. Jundishapur J. Microbiol. 2017, 10, e45645. [CrossRef]

64. Kiang, T.K.L.; Ensom, M.H.H. Therapeutic drug monitoring of mycophenolate in adult solid organ transplant patients: An update. Expert Opin. Drug Metab. Toxicol. 2016, 12, 545-553. [CrossRef] [PubMed]

65. Ferreira, P.C.L.; Thiesen, F.V.; Pereira, A.G.; Zimmer, A.R.; Fröehlich, P.E. A short overview on mycophenolic acid pharmacology and pharmacokinetics. Clin. Transplant. 2020, 34, e13997. [CrossRef]

66. Barau, C.; Mellos, A.; Chhun, S.; Lacaille, F.; Furlan, V. Pharmacokinetics of Mycophenolic Acid and Dose Optimization in Children After Intestinal Transplantation. Ther. Drug Monit. 2017, 39, 37-42. [CrossRef]

67. Martial, L.C.; Jacobs, B.A.W.; Cornelissen, E.A.M.; De Haan, A.F.J.; Koch, B.C.P.; Burger, D.M.; Aarnoutse, R.E.; Schreuder, M.F.; Brüggemann, R.J.M. Pharmacokinetics and target attainment of mycophenolate in pediatric renal transplant patients. Pediatr. Transplant. 2016, 20, 492-499. [CrossRef]

68. Alvarez-Elías, A.C.; Yoo, E.C.; Todorova, E.K.; Singh, R.N.; Filler, G. A Retrospective Study on Mycophenolic Acid Drug Interactions: Effect of Prednisone, Sirolimus, and Tacrolimus With MPA. Ther. Drug Monit. 2017, 39, 220-228. [CrossRef]

69. Tellier, S.; Dallocchio, A.; Guigonis, V.; Saint-Marcoux, F.; Llanas, B.; Ichay, L.; Bandin, F.; Godron, A.; Morin, D.; Brochard, K.; et al. Mycophenolic Acid Pharmacokinetics and Relapse in Children with Steroid-Dependent Idiopathic Nephrotic Syndrome. Clin. J. Am. Soc. Nephrol. 2016, 11, 1777-1782. [CrossRef]

70. Gellermann, J.; Weber, L.; Pape, L.; Tönshoff, B.; Hoyer, P.; Querfeld, U. Mycophenolate Mofetil versus Cyclosporin A in Children with Frequently Relapsing Nephrotic Syndrome. J. Am. Soc. Nephrol. 2013, 24, 1689-1697. [CrossRef]

71. Woillard, J.-B.; Bader-Meunier, B.; Salomon, R.; Ranchin, B.; Decramer, S.; Fischbach, M.; Berard, E.; Guigonis, V.; Harambat, J.; Dunand, O.; et al. Pharmacokinetics of mycophenolate mofetil in children with lupus and clinical findings in favour of therapeutic drug monitoring. Br. J. Clin. Pharmacol. 2014, 78, 867-876. [CrossRef]

72. Barau, C.; Barrail-Tran, A.; Hemerziu, B.; Habes, D.; Taburet, A.-M.; Debray, D.; Furlan, V. Optimization of the dosing regimen of mycophenolate mofetil in pediatric liver transplant recipients. Liver Transplant. 2011, 17, 1152-1158. [CrossRef]

73. Godron-Dubrasquet, A.; Woillard, J.-B.; Decramer, S.; Fila, M.; Guigonis, V.; Tellier, S.; Morin, D.; Sordet, M.; Saint-Marcoux, F.; Harambat, J. Mycophenolic acid area under the concentration-time curve is associated with therapeutic response in childhoodonset lupus nephritis. Pediatr. Nephrol. 2020, 36, 341-347. [CrossRef]

74. Krall, P.; Yañez, D.; Rojo, A.; Delucchi, Á.; Córdova, M.; Morales, J.; Boza, P.; de la Rivera, A.; Espinoza, N.; Armijo, N.; et al. CYP3A5 and UGT1A9 Polymorphisms Influence Immunosuppressive Therapy in Pediatric Kidney Transplant Recipients. Front. Pharmacol. 2021, 12, 653525. [CrossRef]

75. Berger, I.; Haubrich, K.; Ensom, M.H.H.; Carr, R. RELATE: Relationship of limited sampling strategy and adverse effects of mycophenolate mofetil in pediatric renal transplant patients. Pediatr. Transplant. 2019, 23, e13355. [CrossRef]

76. Smits, T.A.; Cox, S.; Fukuda, T.; Sherbotie, J.R.; Ward, R.M.; Goebel, J.; Vinks, A.A. Effects of Unbound Mycophenolic Acid on Inosine Monophosphate Dehydrogenase Inhibition in Pediatric Kidney Transplant Patients. Ther. Drug Monit. 2014, 36, 716-723. [CrossRef]

77. Billing, H.; Höcker, B.; Fichtner, A.; Van Damme-Lombaerts, R.; Friman, S.; Jaray, J.; Vondrak, K.; Sarvary, E.; Strologo, L.D.; Oellerich, M.; et al. Single-Nucleotide Polymorphism of CYP3A5 Impacts the Exposure to Tacrolimus in Pediatric Renal Transplant Recipients: A Pharmacogenetic Substudy of the TWIST Trial. Ther. Drug Monit. 2017, 39, 21-28. [CrossRef]

78. Almardini, R.; Taybeh, E.O.; AlSous, M.M.; Hawwa, A.F.; McKeever, K.; Horne, R.; McElnay, J.C. A multiple methods approach to determine adherence with prescribed mycophenolate in children with kidney transplant. Br. J. Clin. Pharmacol. 2019, 85, 1434-1442. [CrossRef] 
79. Dong, M.; Fukuda, T.; Cox, S.; De Vries, M.T.; Hooper, D.K.; Goebel, J.; Vinks, A.A. Population pharmacokinetic-pharmacodynamic modelling of mycophenolic acid in paediatric renal transplant recipients in the early post-transplant period. Br. J. Clin. Pharmacol. 2014, 78, 1102-1112. [CrossRef]

80. Fukuda, T.; Goebel, J.; Thøgersen, H.; Maseck, D.; Cox, S.; Logan, B.; Sherbotie, J.; Seikaly, M.; Vinks, A.A. Inosine Monophosphate Dehydrogenase (IMPDH) Activity as a Pharmacodynamic Biomarker of Mycophenolic Acid Effects in Pediatric Kidney Transplant Recipients. J. Clin. Pharmacol. 2011, 51, 309-320. [CrossRef]

81. Fukuda, T.; Goebel, J.; Cox, S.; Maseck, D.; Zhang, K.; Sherbotie, J.R.; Ellis, E.N.; James, L.P.; Ward, R.M.; Vinks, A. UGT1A9, UGT2B7, and MRP2 Genotypes Can Predict Mycophenolic Acid Pharmacokinetic Variability in Pediatric Kidney Transplant Recipients. Ther. Drug Monit. 2012, 34, 671-679. [CrossRef]

82. Siddiqi, N.; Lamour, J.M.; Hsu, D.T. The effect of MMF dose and trough levels on adverse effects in pediatric heart transplant recipients. Pediatr. Transplant. 2015, 19, 618-622. [CrossRef]

83. Burckart, G.J.; Figg, W.D.; Brooks, M.M.; Green, D.J.; Troutman, S.M.; Ferrell, R.; Chinnock, R.; Canter, C.; Addonizio, L.; Bernstein, D.; et al. Multi-institutional Study of Outcomes After Pediatric Heart Transplantation: Candidate Gene Polymorphism Analysis of ABCC2. J. Pediatr. Pharmacol. Ther. 2014, 19, 16-24. [CrossRef]

84. Militano, O.; Ozkaynak, M.F.; Mehta, B.; Van Deven, C.; Hamby, C.; Cairo, M.S. Mycophenolate mofetil administered every 8 hours in combination with tacrolimus is efficacious in the prophylaxis of acute graft versus host disease in childhood, adolescent, and young adult allogeneic stem cell transplantation recipients. Pediatr. Blood Cancer 2018, 65, e27091. [CrossRef]

85. Zhang, D.; Renbarger, J.L.; Chow, D.S.-L. Pharmacokinetic Variability of Mycophenolic Acid in Pediatric and Adult Patients With Hematopoietic Stem Cell Transplantation. J. Clin. Pharmacol. 2016, 56, 1378-1386. [CrossRef]

86. Inagaki, J.; Kodama, Y.; Fukano, R.; Noguchi, M.; Okamura, J. Mycophenolate mofetil for treatment of steroid-refractory acute graft-versus-host disease after pediatric hematopoietic stem cell transplantation. Pediatr. Transplant. 2015, 19, 652-658. [CrossRef]

87. Windreich, R.M.; Goyal, R.K.; Joshi, R.; Kenkre, T.S.; Howrie, D.; Venkataramanan, R. A Pilot Study of Continuous Infusion of Mycophenolate Mofetil for Prophylaxis of Graft-versus-Host-Disease in Pediatric Patients. Biol. Blood Marrow Transplant. 2015, 22, 682-689. [CrossRef]

88. Carlone, G.; Simeone, R.; Baraldo, M.; Maestro, A.; Zanon, D.; Barbi, E.; Maximova, N. Area-Under-the-Curve-Based Mycophenolate Mofetil Dosage May Contribute to Decrease the Incidence of Graft-versus-Host Disease after Allogeneic Hematopoietic Cell Transplantation in Pediatric Patients. J. Clin. Med. 2021, 10, 406. [CrossRef]

89. Kim, H.; Long-Boyle, J.; Rydholm, N.; Orchard, P.J.; Tolar, J.; Smith, A.R.; Jacobson, P.; Brundage, R. Population pharmacokinetics of unbound mycophenolic acid in pediatric and young adult patients undergoing allogeneic hematopoietic cell transplantation. $J$. Clin. Pharmacol. 2012, 52, 1665-1675. [CrossRef]

90. Harnicar, S.; Ponce, D.M.; Hilden, P.; Zheng, J.; Devlin, S.M.; Lubin, M.; Pozotrigo, M.; Mathew, S.; Adel, N.; Kernan, N.; et al. Intensified Mycophenolate Mofetil Dosing and Higher Mycophenolic Acid Trough Levels Reduce Severe Acute Graft-versus-Host Disease after Double-Unit Cord Blood Transplantation. Biol. Blood Marrow Transplant. 2015, 21, 920-925. [CrossRef]

91. Hui-Yuen, J.S.; Tran, T.; Taylor, J.; Truong, K.; Li, X.; Bermudez, L.M.; Starr, A.J.; Eichenfield, A.H.; Imundo, L.F.; Askanase, A.D. Use of Glucuronidated Mycophenolic Acid Levels for Therapeutic Monitoring in Pediatric Lupus Nephritis Patients. J. Clin. Rheumatol. 2016, 22, 75-79. [CrossRef]

92. Chen, Y.; Sun, L.; Xu, H.; Dong, M.; Mizuno, T.; Vinks, A.A.; Brunner, H.I.; Li, Y.; Li, Z. PK/PD Study of Mycophenolate Mofetil in Children With Systemic Lupus Erythematosus to Inform Model-Based Precision Dosing. Front. Pharmacol. 2020, $11,2201$. [CrossRef] [PubMed]

93. Sagcal-Gironella, A.C.P.; Fukuda, T.; Wiers, K.; Cox, S.; Nelson, S.; Dina, B.; Sherwin, C.M.T.; Klein-Gitelman, M.S.; Vinks, A.A.; Brunner, H.I. Pharmacokinetics and Pharmacodynamics of Mycophenolic Acid and Their Relation to Response to Therapy of Childhood-Onset Systemic Lupus Erythematosus. Semin. Arthritis Rheum. 2011, 40, 307-313. [CrossRef] [PubMed]

94. Ye, Q.; Wang, G.; Huang, Y.; Lu, J.; Zhang, J.; Zhu, L.; Zhu, Y.; Li, X.; Lan, J.; Li, Z.; et al. Mycophenolic Acid Exposure Optimization Based on Vitamin D Status in Children with Systemic Lupus Erythematosus: A Single-Center Retrospective Study. Rheumatol. Ther. 2021, 8, 1143-1157. [CrossRef] [PubMed]

95. Fukuda, T.; Brunner, H.I.; Sagcal-Gironella, A.C.P.; Vinks, A.A. Nonsteroidal Anti-Inflammatory Drugs May Reduce Enterohepatic Recirculation of Mycophenolic Acid in Patients With Childhood-Onset Systemic Lupus Erythematosus. Ther. Drug Monit. 2011, 33, 658-662. [CrossRef]

96. Ye, Q.; Wang, G.; Lu, J.; Huang, Y.; Zhang, J.; Zhu, L.; Zhu, Y.; Lan, J.; Li, Z.; Liu, Y.; et al. Exposure levels of mycophenolic acid are associated with comorbidities in children with systemic lupus erythematosus. Lupus 2021, 30, 1808-1818. [CrossRef]

97. Sobiak, J.; Resztak, M.; Ostalska-Nowicka, D.; Zachwieja, J.; Gasiorowska, K.; Piechanowska, W.; Chrzanowska, M. Monitoring of mycophenolate mofetil metabolites in children with nephrotic syndrome and the proposed novel target values of pharmacokinetic parameters. Eur. J. Pharm. Sci. 2015, 77, 189-196. [CrossRef]

98. Benz, M.R.; Ehren, R.; Kleinert, D.; Müller, C.; Gellermann, J.; Fehrenbach, H.; Schmidt, H.; Weber, L.T. Generation and Validation of a Limited Sampling Strategy to Monitor Mycophenolic Acid Exposure in Children With Nephrotic Syndrome. Ther. Drug Monit. 2019, 41, 696-702. [CrossRef]

99. Kirpalani, A.; Rothfels, L.; Sharma, A.P.; Cuellar, C.R.; Filler, G. Nephrotic state substantially enhances apparent mycophenolic acid clearance. Clin. Nephrol. 2019, 91, 162-171. [CrossRef] 
100. Hibino, S.; Nagai, T.; Yamakawa, S.; Ito, H.; Tanaka, K.; Uemura, O. Pharmacokinetics of mycophenolic acid in children with clinically stable idiopathic nephrotic syndrome receiving cyclosporine. Clin. Exp. Nephrol. 2016, 21, 152-158. [CrossRef]

101. Baudouin, V.; Alberti, C.; Lapeyraque, A.-L.; Bensman, A.; André, J.-L.; Broux, F.; Cailliez, M.; Decramer, S.; Niaudet, P.; Deschênes, G.; et al. Mycophenolate mofetil for steroid-dependent nephrotic syndrome: A phase II Bayesian trial. Pediatr. Nephrol. 2011, 27, 389-396. [CrossRef]

102. Hackl, Á.; Cseprekál, O.; Gessner, M.; Liebau, M.C.; Habbig, S.; Ehren, R.; Müller, C.; Taylan, C.; Dötsch, J.; Weber, L.T. Mycophenolate Mofetil Therapy in Children With Idiopathic Nephrotic Syndrome: Does Therapeutic Drug Monitoring Make a Difference? Ther. Drug Monit. 2016, 38, 274-279. [CrossRef]

103. Saint-Marcoux, F.; Guigonis, V.; Decramer, S.; Gandia, P.; Ranchin, B.; Parant, F.; Bessenay, L.; Libert, F.; Harambat, J.; Bouchet, S.; et al. Development of a Bayesian estimator for the therapeutic drug monitoring of mycophenolate mofetil in children with idiopathic nephrotic syndrome. Pharmacol. Res. 2011, 63, 423-431. [CrossRef]

104. Gellermann, J.; Ehrich, J.H.H.; Querfeld, U. Sequential maintenance therapy with cyclosporin A and mycophenolate mofetil for sustained remission of childhood steroid-resistant nephrotic syndrome. Nephrol. Dial. Transplant. 2011, 27, 1970-1978. [CrossRef]

105. Sobiak, J.; Resztak, M.; Pawiński, T.; Żero, P.; Ostalska-Nowicka, D.; Zachwieja, J.; Chrzanowska, M. Limited sampling strategy to predict mycophenolic acid area under the curve in pediatric patients with nephrotic syndrome: A retrospective cohort study. Eur. J. Clin. Pharmacol. 2019, 75, 1249-1259. [CrossRef]

106. Tong, K.; Mao, J.; Fu, H.; Shen, H.; Liu, A.; Shu, Q.; Du, L. The Value of Monitoring the Serum Concentration of Mycophenolate Mofetil in Children with Steroid-Dependent/Frequent Relapsing Nephrotic Syndrome. Nephron 2016, 132, 327-334. [CrossRef]

107. Sobiak, J.; Jóźwiak, A.; Wziętek, H.; Zachwieja, J.; Ostalska-Nowicka, D. The Application of Inosine 5'-Monophosphate Dehydrogenase Activity Determination in Peripheral Blood Mononuclear Cells for Monitoring Mycophenolate Mofetil Therapy in Children with Nephrotic Syndrome. Pharmaceuticals 2020, 13, 200. [CrossRef]

108. Hackl, A.; Becker, J.U.; Körner, L.M.; Ehren, R.; Habbig, S.; Nüsken, E.; Nüsken, K.-D.; Ebner, K.; Liebau, M.C.; Müller, C.; et al. Mycophenolate mofetil following glucocorticoid treatment in Henoch-Schönlein purpura nephritis: The role of early initiation and therapeutic drug monitoring. Pediatr. Nephrol. 2017, 33, 619-629. [CrossRef]

109. Nakaseko, H.; Iwata, N.; Yasuoka, R.; Kohagura, T.; Abe, N.; Kawabe, S.; Mori, M. Pharmacokinetics of mycophenolate mofetil in juvenile patients with autoimmune diseases. Mod. Rheumatol. 2019, 29, 1002-1006. [CrossRef]

110. Staatz, C.E.; Tett, S.E. Clinical Pharmacokinetics and Pharmacodynamics of Mycophenolate in Solid Organ Transplant Recipients. Clin. Pharmacokinet. 2007, 46, 13-58. [CrossRef]

111. Allison, A.C. Mechanisms of action of mycophenolate mofetil. Lupus 2005, 14, 2-8. [CrossRef]

112. Todorova, E.K.; Huang, S.-H.S.; Kobrzynski, M.C.; Filler, G. What is the intrapatient variability of mycophenolic acid trough levels? Pediatr. Transplant. 2015, 19, 669-674. [CrossRef]

113. Sobiak, J.; Resztak, M. A Systematic Review of Multiple Linear Regression-Based Limited Sampling Strategies for Mycophenolic Acid Area Under the Concentration-Time Curve Estimation. Eur. J. Drug Metab. Pharmacokinet. 2021, 46, 721-742. [CrossRef]

114. Filler, G.; Todorova, E.K.; Bax, K.; Alvarez-Elías, A.C.; Huang, S.-H.S.; Kobrzynski, M.C. Minimum mycophenolic acid levels are associated with donor-specific antibody formation. Pediatr. Transplant. 2015, 20, 34-38. [CrossRef]

115. Fujinaga, S.; Someya, T.; Watanabe, T.; Ito, A.; Ohtomo, Y.; Shimizu, T.; Kaneko, K. Cyclosporine versus mycophenolate mofetil for maintenance of remission of steroid-dependent nephrotic syndrome after a single infusion of rituximab. Eur. J. Nucl. Med. Mol. Imaging 2012, 172, 513-518. [CrossRef]

116. Liu, Y.; Liu, L.; Li, J.; Fu, Q.; Zhang, H.; Wu, C.; Li, J.; Zhong, G.; Zheng, Y.; Chen, X.; et al. Validated LC-MS/MS method for quantitation of total and free mycophenolic acid concentration and its application to a pharmacokinetic study in pediatric renal transplant recipients. Biomed. Chromatogr. 2020, 35, e4989. [CrossRef]

117. Rother, A.; Glander, P.; Vitt, E.; Czock, D.; Von Ahsen, N.; Armstrong, V.W.; Oellerich, M.; Budde, K.; Feneberg, R.; Tönshoff, B.; et al. Inosine monophosphate dehydrogenase activity in paediatrics: Age-related regulation and response to mycophenolic acid. Eur. J. Clin. Pharmacol. 2012, 68, 913-922. [CrossRef]

118. Filler, G.; Bendrick-Peart, J.; Christians, U. Pharmacokinetics of Mycophenolate Mofetil and Sirolimus in Children. Ther. Drug Monit. 2008, 30, 138-142. [CrossRef]

119. Yoo, E.C.; Alvarez-Elías, A.C.; Todorova, E.K.; Filler, G. Developmental changes of MPA exposure in children. Pediatr. Nephrol. 2016, 31, 975-982. [CrossRef] [PubMed]

120. Prémaud, A.; Rousseau, A.; Le Meur, Y.; Lachâtre, G.; Marquet, P. Comparison of Liquid Chromatography-Tandem Mass Spectrometry with a Commercial Enzyme-Multiplied Immunoassay for the Determination of Plasma MPA in Renal Transplant Recipients and Consequences for Therapeutic Drug Monitoring. Ther. Drug Monit. 2004, 26, 609-619. [CrossRef] [PubMed]

121. Kunicki, P.K.; Pawinski, T.; Boczek, A.; Waś, J.; Bodnar-Broniarczyk, M. A Comparison of the Immunochemical Methods, PETINIA and EMIT, With That of HPLC-UV for the Routine Monitoring of Mycophenolic Acid in Heart Transplant Patients. Ther. Drug Monit. 2015, 37, 311-318. [CrossRef] [PubMed]

122. Alsmadi, M.M.; Alfarah, M.Q.; Albderat, J.; Alsalaita, G.; Almardini, R.; Hamadi, S.; Al-Ghazawi, A.; Abu-Duhair, O.; Idkaidek, N. The development of a population physiologically based pharmacokinetic model for mycophenolic mofetil and mycophenolic acid in humans using data from plasma, saliva, and kidney tissue. Biopharm. Drug Dispos. 2019, 40, 325-340. [CrossRef] 
123. Wiesen, M.H.J.; Farowski, F.; Feldkötter, M.; Hoppe, B.; Müller, C. Liquid chromatography-tandem mass spectrometry method for the quantification of mycophenolic acid and its phenolic glucuronide in saliva and plasma using a standardized saliva collection device. J. Chromatogr. A 2012, 1241, 52-59. [CrossRef]

124. Gonzalez-Ramirez, R.; González-Bañuelos, J.; Villa, M.D.L.S.; Jiménez, B.; García-Roca, P.; Cruz-Antonio, L.; CastañedaHernández, G.; Medeiros, M. Bioavailability of a generic of the immunosuppressive agent mycophenolate mofetil in pediatric patients. Pediatr. Transplant. 2014, 18, 568-574. [CrossRef]

125. Olson, J.; Hersh, A.L.; Sorensen, J.; Zobell, J.; Anderson, C.; Thorell, E.A. Intravenous Vancomycin Therapeutic Drug Monitoring in Children: Evaluation of a Pharmacy-Driven Protocol and Collaborative Practice Agreement. J. Pediatr. Infect. Dis. Soc. 2019, 9, 334-341. [CrossRef]

126. Tkachuk, S.; Collins, K.; Ensom, M.H.H. The Relationship Between Vancomycin Trough Concentrations and AUC/MIC Ratios in Pediatric Patients: A Qualitative Systematic Review. Pediatr. Drugs 2018, 20, 153-164. [CrossRef]

127. Rybak, M.J.; Lomaestro, B.M.; Rotscahfer, J.C.; Moellering, J.R.C.; Craig, W.A.; Billeter, M.; Dalovisio, J.R.; Levine, D.P. Vancomycin Therapeutic Guidelines: A Summary of Consensus Recommendations from the Infectious Diseases Society of America, the American Society of Health-System Pharmacists, and the Society of Infectious Diseases Pharmacists. Clin. Infect. Dis. 2009, 49, 325-327. [CrossRef]

128. Fitzgerald, J.C.; Zane, N.R.; Himebauch, A.S.; Reedy, M.D.; Downes, K.J.; Topjian, A.A.; Furth, S.L.; Thomas, N.J.; Scheetz, M.H.; Zuppa, A.F. Vancomycin Prescribing and Therapeutic Drug Monitoring in Children With and Without Acute Kidney Injury After Cardiac Arrest. Pediatr. Drugs 2019, 21, 107-112. [CrossRef]

129. Rybak, M.; Lomaestro, B.; Rotschafer, J.C.; Moellering, R.; Craig, W.; Billeter, M.; Dalovisio, J.R.; Levine, D.P. Therapeutic monitoring of vancomycin in adult patients: A consensus review of the American Society of Health-System Pharmacists, the Infectious Diseases Society of America, and the Society of Infectious Diseases Pharmacists. Am. J. Heal. Pharm. 2009, 66, 82-98. [CrossRef]

130. Liu, C.; Bayer, A.; Cosgrove, S.E.; Daum, R.S.; Fridkin, S.K.; Gorwitz, R.J.; Kaplan, S.L.; Karchmer, A.W.; Levine, D.P.; Murray, B.E.; et al. Clinical Practice Guidelines by the Infectious Diseases Society of America for the Treatment of MethicillinResistant Staphylococcus aureus Infections in Adults and Children. Clin. Infect. Dis. 2011, 52, e18-e55. [CrossRef]

131. Frymoyer, A.; Guglielmo, B.J.; Hersh, A.L. Desired Vancomycin Trough Serum Concentration for Treating Invasive Methicillinresistant Staphylococcal Infections. Pediatr. Infect. Dis. J. 2013, 32, 1077-1079. [CrossRef]

132. Le, J.; Bradley, J.S.; Murray, W.; Romanowski, G.L.; Tran, T.T.; Nguyen, N.; Cho, S.; Natale, S.; Bui, I.; Tran, T.M.; et al. Improved Vancomycin Dosing in Children Using Area Under the Curve Exposure. Pediatr. Infect. Dis. J. 2013, 32, e155-e163. [CrossRef]

133. Moriyama, H.; Tsutsuura, M.; Kojima, N.; Mizukami, Y.; Tashiro, S.; Osa, S.; Enoki, Y.; Taguchi, K.; Oda, K.; Fujii, S.; et al. The optimal trough-guided monitoring of vancomycin in children: Systematic review and meta-analyses. J. Infect. Chemother. 2021, 27, 781-785. [CrossRef]

134. Fiorito, T.M.; Luther, M.K.; Dennehy, P.H.; LaPlante, K.L.; Matson, K.L. Nephrotoxicity With Vancomycin in the Pediatric Population: A Systematic Review and Meta-Analysis. Pediatr. Infect. Dis. J. 2018, 37, 654-661. [CrossRef]

135. Hahn, A.; Frenck, R.W.; Allen-Staat, M.; Zou, Y.; Vinks, A.A. Evaluation of Target Attainment of Vancomycin Area Under the Curve in Children With Methicillin-Resistant Staphylococcus Aureus Bacteremia. Ther. Drug Monit. 2015, 37, 619-625. [CrossRef]

136. Downes, K.J.; Hahn, A.; Wiles, J.; Courter, J.D.; Vinks, A.A. Dose optimisation of antibiotics in children: Application of pharmacokinetics/pharmacodynamics in paediatrics. Int. J. Antimicrob. Agents 2013, 43, 223-230. [CrossRef]

137. Dosing and Monitoring of Vancomycin in Pediatric Patients. Available online: https://Www.Med.Umich.Edu/Asp/Pdf/Pk/ Vancomycin_Peds.Pdf (accessed on 26 October 2021).

138. Khare, M.; Azim, A.; Kneese, G.; Haag, M.; Weinstein, K.; Rhee, K.E.; Foster, B.A. Vancomycin Dosing in Children With Overweight or Obesity: A Systematic Review and Meta-analysis. Hosp. Pediatr. 2020, 10, 359-368. [CrossRef]

139. Butterfield, J.M.; Patel, N.; Pai, M.P.; Rosano, T.G.; Drusano, G.L.; Lodise, T.P. Refining Vancomycin Protein Binding Estimates: Identification of Clinical Factors That Influence Protein Binding. Antimicrob. Agents Chemother. 2011, 55, 4277-4282. [CrossRef]

140. Berthoin, K.; Ampe, E.; Tulkens, P.M.; Carryn, S. Correlation between free and total vancomycin serum concentrations in patients treated for Gram-positive infections. Int. J. Antimicrob. Agents 2009, 34, 555-560. [CrossRef] [PubMed]

141. Oyaert, M.; Spriet, I.; Allegaert, K.; Smits, A.; Vanstraelen, K.; Peersman, N.; Wauters, J.; Verhaegen, J.; Vermeersch, P.; Pauwels, S. Factors Impacting Unbound Vancomycin Concentrations in Different Patient Populations. Antimicrob. Agents Chemother. 2015, 59, 7073-7079. [CrossRef] [PubMed]

142. Stove, V.; Coene, L.; Carlier, M.; De Waele, J.J.; Fiers, T.; Verstraete, A.G. Measuring Unbound Versus Total Vancomycin Concentrations in Serum and Plasma: Methodological Issues and Relevance. Ther. Drug Monit. 2015, 37, 180-187. [CrossRef] [PubMed]

143. Durward, A.; Mayer, A.; Skellett, S.; Taylor, D.; Hanna, S.; Tibby, S.M.; Murdoch, I.A. Hypoalbuminaemia in critically ill children: Incidence, prognosis, and influence on the anion gap. Arch. Dis. Child. 2003, 88, 419-422. [CrossRef]

144. Chen, Y.; Norris, R.L.G.; Schneider, J.J.; Ravenscroft, P.J. The influence of vancomycin concentration and the $\mathrm{pH}$ of plasma on vancomycin protein binding. J. Pharmacol. Toxicol. Methods 1992, 28, 57-60. [CrossRef]

145. Kees, M.G.; Wicha, S.G.; Seefeld, A.; Kees, F.; Kloft, C. Unbound fraction of vancomycin in intensive care unit patients. J. Clin. Pharmacol. 2013, 54, 318-323. [CrossRef] 
146. Lichliter, R.L.; Tremewan, L.E.; Shonka, N.M.; Mehnert, J.E.; Brennan, L.; Thrasher, J.M.; Hernandez, T.L. Therapeutic antibiotic serum concentrations by two blood collection methods within the pediatric patient: A comparative effectiveness trial. J. Spéc. Pediatr. Nurs. 2018, 23, e12212. [CrossRef]

147. McKamy, S.; Hernandez, E.; Jahng, M.; Moriwaki, T.; Deveikis, A.; Le, J. Incidence and Risk Factors Influencing the Development of Vancomycin Nephrotoxicity in Children. J. Pediatr. 2011, 158, 422-426. [CrossRef]

148. De Cock, P.A.J.G.; Desmet, S.; De Jaeger, A.; Biarent, D.; Dhont, E.; Herck, I.; Vens, D.; Colman, S.; Stove, V.; Commeyne, S.; et al. Impact of vancomycin protein binding on target attainment in critically ill children: Back to the drawing board? J. Antimicrob. Chemother. 2016, 72, 801-804. [CrossRef] [PubMed]

149. Giachetto, G.A.; Telechea, H.M.; Speranza, N.; Oyarzun, M.; Nanni, L.; Menchaca, A. Vancomycin pharmacokineticpharmacodynamic parameters to optimize dosage administration in critically ill children. Pediatr. Crit. Care Med. 2011, 12, e250-e254. [CrossRef]

150. Dolan, E.; Hellinga, R.; London, M.; Ryan, K.; Dehority, W. Effect of Vancomycin Loading Doses on the Attainment of Target Trough Concentrations in Hospitalized Children. J. Pediatr. Pharmacol. Ther. 2020, 25, 423-430. [CrossRef]

151. Da Silva Alves, G.C.; Da Silva, S.D.; Frade, V.P.; Rodrigues, D.; Baldoni, A.D.O.; De Castro, W.V.; Sanches, C. Determining the optimal vancomycin daily dose for pediatrics: A meta-analysis. Eur. J. Clin. Pharmacol. 2017, 73, 1341-1353. [CrossRef]

152. Vancomycin Dosing and Pharmacokinetics in Postoperative Pediatric Cardiothoracic Surgery Patients. Available online: https: / / www.ncbi.nlm.nih.gov/pmc/articles/PMC4778698 (accessed on 30 June 2021).

153. Moffett, B.S.; Hilvers, P.S.; Dinh, K.; Arikan, A.A.; Checchia, P.; Bronicki, R. Vancomycin-Associated Acute Kidney Injury in Pediatric Cardiac Intensive Care Patients. Congenit. Hear. Dis. 2014, 10, E6-E10. [CrossRef]

154. Cies, J.J.; Shankar, V. Nephrotoxicity in Patients with Vancomycin Trough Concentrations of 15-20 $\mu \mathrm{g} / \mathrm{ml}$ in a Pediatric Intensive Care Unit. Pharmacother. J. Hum. Pharmacol. Drug Ther. 2013, 33, 392-400. [CrossRef] [PubMed]

155. Hays, W.B.; Tillman, E. Vancomycin-Associated Acute Kidney Injury in Critically Ill Adolescent and Young Adult Patients. J. Pharm. Pr. 2019, 33, 749-753. [CrossRef] [PubMed]

156. Lanke, S.; Yu, T.; Rower, J.E.; Balch, A.H.; Korgenski, E.K.; Sherwin, C.M. AUC-Guided Vancomycin Dosing in Adolescent Patients With Suspected Sepsis. J. Clin. Pharmacol. 2016, 57, 77-84. [CrossRef] [PubMed]

157. Morgan, R.W.; Fitzgerald, J.C.; Weiss, S.L.; Nadkarni, V.M.; Sutton, R.M.; Berg, R.A. Sepsis-associated in-hospital cardiac arrest: Epidemiology, pathophysiology, and potential therapies. J. Crit. Care 2017, 40, 128-135. [CrossRef]

158. Zane, N.R.; Reedy, M.D.; Gastonguay, M.R.; Himebauch, A.S.; Ramsey, E.Z.; Topjian, A.A.; Zuppa, A.F. A Population Pharmacokinetic Analysis to Study the Effect of Therapeutic Hypothermia on Vancomycin Disposition in Children Resuscitated From Cardiac Arrest. Pediatr. Crit. Care Med. 2017, 18, e290-e297. [CrossRef]

159. Benjanuwattra, J.; Chaiyawat, P.; Pruksakorn, D.; Koonrungsesomboon, N. Therapeutic potential and molecular mechanisms of mycophenolic acid as an anticancer agent. Eur. J. Pharmacol. 2020, 887, 173580. [CrossRef]

160. Bergan, S.; Brunet, M.; Hesselink, D.A.; Johnson-Davis, K.L.; Kunicki, P.K.; Lemaitre, F.; Marquet, P.; Molinaro, M.; Noceti, O.; Pattanaik, S.; et al. Personalized Therapy for Mycophenolate: Consensus Report by the International Association of Therapeutic Drug Monitoring and Clinical Toxicology. Ther. Drug Monit. 2021, 43, 150-200. [CrossRef] 